\title{
Article \\ Elucidation of Phytochemical Content of Cupressus macrocarpa Leaves: In Vitro and In Vivo Antibacterial Effect against Methicillin-Resistant Staphylococcus aureus Clinical Isolates
}

\author{
Nashwah G. M. Attallah ${ }^{1,2,+}$, Walaa A. Negm ${ }^{3,+} \mathbb{C}^{\mathbb{D}}$, Engy Elekhnawy ${ }^{4, *} \mathbb{(}$, Elshaymaa I. Elmongy ${ }^{1,5, *}$, \\ Najla Altwaijry ${ }^{1}{ }^{\circledR}$, Hala El-Haroun ${ }^{6}$, Thanaa A. El-Masry ${ }^{7}$ and Suzy A. El-Sherbeni ${ }^{3}$
}

1 Pharmaceutical Sciences Department, College of Pharmacy, Princess Nourah Bint Abdulrahman University, Riyadh 84428, Saudi Arabia; ngmohamed@pnu.edu.sa (N.G.M.A.); naaltwaijry@pnu.edu.sa (N.A.)

2 Egyptian Drug Authority (EDA), Giza 8655, Egypt (previously NODCAR)

3 Pharmacognosy Department, Faculty of Pharmacy, Tanta University, Tanta 31111, Egypt; walaa.negm@pharm.tanta.edu.eg (W.A.N.); suzy.elsherbini@pharm.tanta.edu.eg (S.A.E.-S.)

4 Pharmaceutical Microbiology Department, Faculty of Pharmacy, Tanta University, Tanta 31111, Egypt

5 Pharmaceutical Chemistry Department, Faculty of Pharmacy, Helwan University, Helwan 11795, Egypt

6 Histology Department, Faculty of Medicine, Menoufia University, Shibin Al Kawm 32511, Egypt; elharoun@yahoo.com

check for
updates

Citation: Attallah, N.G.M.; Negm, W.A.; Elekhnawy, E.; Elmongy, E.I.; Altwaijry, N.; El-Haroun, H.; El-Masry, T.A.; El-Sherbeni, S.A. Elucidation of Phytochemical Content of Cupressus macrocarpa Leaves: In Vitro and In Vivo Antibacterial Effect against Methicillin-Resistant Staphylococcus aureus Clinical Isolates. Antibiotics 2021, 10, 890. https:/ / doi.org/10.3390/antibiotics10080890

Academic Editors:

Emanuela Roscetto and

Claudia Ciniglia

Received: 16 June 2021

Accepted: 15 July 2021

Published: 22 July 2021

Publisher's Note: MDPI stays neutral with regard to jurisdictional claims in published maps and institutional affiliations.

Copyright: (c) 2021 by the authors. Licensee MDPI, Basel, Switzerland. This article is an open access article distributed under the terms and conditions of the Creative Commons Attribution (CC BY) license (https:/ / creativecommons.org/licenses/by/ $4.0 /)$.
7 Pharmacology Department, Faculty of Pharmacy, Tanta University, Tanta 31111, Egypt; thanaa.elmasri@pharm.tanta.edu.eg

* Correspondence: engy.ali@pharm.tanta.edu.eg (E.E.); eielmongy@pnu.edu.sa or Shaymaa.Taha@pharm.helwan.edu.eg (E.I.E.)

+ These authors contributed equally to this work.

Abstract: Methicillin-resistant Staphylococcus aureus (MRSA) is an important human pathogen that causes various infections. The increasing resistance of MRSA to different antibiotics is widely spreading; therefore, plant extracts may be novel therapeutic alternatives. The phytochemical profiling of Cupressus macrocarpa Hartw. ex Gordon leaves in vitro, and in vivo, antimicrobial potential of its extracts against MRSA clinical isolates were explored. A phytochemical tentative identification of 49 compounds was performed in the leaves using LC-ESI-MS/MS; in addition, isolation, and structure elucidation of hesperidin and eriocitrin were achieved for the first time. The diethyl ether extract (DEEL) exhibited the best antibacterial effect with MIC values ranging from 2 to $8 \mu \mathrm{g} / \mathrm{mL}$, which significantly reduced the growth and efflux activity in $48.78 \%$ and $29.26 \%$ of isolates, respectively. qRT-PCR showed a significant down expression of nor A and norB genes, which significantly affected the bacterial cell morphology and had a non-significant effect on membrane depolarization (using flow cytometry). In a rat model, four groups were wounded and treated with normal saline or DEEL, or infected with MRSA, or infected and treated with DEEL. The regeneration of the epidermis, maturation of granulation tissue, and reduction of inflammatory cell infiltration were observed after treatment with DEEL. Thus, C. macrocarpa leaves may be a promising source for new antimicrobials against MRSA.

Keywords: trichrome stain; membrane depolarization; mecA gene; qRT-PCR; SEM

\section{Introduction}

Cupressus macrocarpa Hartw. ex Gordon (Callitropsis macrocarpa) or Monterey cypress (family Cupressaceae) [1,2] is a well-known ornamental tree. It is a gymnosperm plant widely distributed in the United States of America, and warm temperate and subtropical regions in Europe, New Zealand, North Africa, and Asia. It is commonly used as an ornament and for windbreaks [3]. It was used traditionally for decades to treat different diseases and ailments, e.g., whooping cough, as a styptic, to eliminate fluid retention, and rheumatism [4]. 
C. macrocarpa leaves and branchlets are rich in essential oils [5,6] composed mainly of monoterpenes and traces of sesquiterpenes [7] as well as diterpenes [8], flavonoids, biflavonoids [4,9], and other compounds. The diethyl ether extract is composed mainly of essential oil and non-volatile components, e.g., diterpenes and diterpenoids [10]. It is reported that the essential oils possess a powerful antimicrobial effect [6] and, according to the literature [11], the Essential Oils (Eos) of C. macrocarpa have an antifungal effect against Trichophyton rubrum, a specific dermal fungus. This was the motive to extensively study the antibacterial effect of $C$. macrocarpa.

Flavonoids are bioactive common components of plants with diverse and remarkable biological activities such as antioxidant or free radical scavenging, anti-inflammatory [12], cardioprotective [13], anticarcinogenic [14], antimicrobial [15], and antiviral [16] activities.

They have a basic $C_{15}$ phenyl-benzopyrone nucleus, which is biosynthesized from shikimic and acetic or malonic acid precursors. Their structures earn their diversity through differing numbers and positions of substituents including hydroxyl, methoxyl, and glycosyl groups. Glycosides may be of $\mathrm{O}_{-}, \mathrm{C}_{-}$, or $\mathrm{O}$ - and $\mathrm{C}$-types. Biflavonoids are dimers of flavonoids, usually flavones and flavanones. The interflavonoid linkage is either a $\mathrm{C}-\mathrm{C}$ bond or occasionally an ether bond. The prevalent C-C attached types are: $6,8^{\prime \prime}$-linked (agathisflavone group), 8,8' $8^{\prime \prime}$-linked (cupressuflavone group), $3^{\prime}, 8^{\prime \prime}$-linked (amentoflavone group) and others. These compounds are restricted in distribution, to be found prevalently in Gymnosperms [17].

Phytochemical investigation of flavonoids, biflavonoids, and other compounds for C. macrocarpa leaves was not previously studied. In this study, chemical profiling was achieved by LC-ESI-MS/MS technique, which supplied us with valuable data about this plant.

The nontargeting small molecule comprehensive analysis of large-scale plant metabolomics that depend on liquid chromatography coupled with electrospray ionization tandem mass spectrometry (LC-ESI-MS/MS) is considered a ubiquitous technique for recognition of different natural products in plants as it can enrich us with information about molecular mass, molecular fragmentation, molecular formula, the relative abundance of different components, as well as determining the type of glycosides and position of substituents.

Staphylococcus aureus is an important human pathogenic bacterium that can cause various infections ranging from superficial skin infections to fatal systemic infections [18]. S. aureus is considered one of the leading causes of nosocomial infections worldwide [19]. The misuse of penicillin has resulted in the emergence of penicillin-resistant $S$. aureus. In addition, the more problematic bacteria, methicillin-resistant $S$. aureus (MRSA), have started to spread around the world, causing high rates of morbidity and mortality [20]. This health care problem necessitates the exploring for novel, natural compounds with an antibacterial effect against MRSA isolates. Plants are usually used traditionally for the treatment of certain diseases; thus, many researchers have focused on exploring the antibacterial activity of different plants [21].

This study was conducted to investigate the phytochemical constituents of $C$. macrocarpa leaves by LC-ESI-MS/MS analysis of the methanol extract of defatted leaves. To the best of our knowledge, there are no reports concerning the antibacterial impact of $C$. macrocarpa leaf extracts against MRSA isolates. Therefore, an inspection of the potential in vitro and in vivo antibacterial effect of $C$. macrocarpa leaf extracts against MRSA isolates was carried out.

\section{Results}

\subsection{Results of LC-ESI-MS/MS Analysis of C. Macrocarpa Leaves Methanol Extract}

In the current study, the data-independent acquisition-based identification by mass spectral deconvolution using MS-DIAL in LC-ESI-MS/MS analysis (negative mode ESI) of C. macrocarpa leaves methanol extract revealed the tentative identification of 49 compounds of phenolic acids, flavones, flavonols, flavanones, isoflavones, biflavonoids, catechin, stilbene glycosides, and diterpenes. Flavonoids aglycones, $\mathrm{O}$ - and $\mathrm{C}$-glycosides were iden- 
tified. Results are listed in Table 1. The total ion chromatogram (TIC) of methanol extract of C. macrocarpa leaves (negative mode) is presented in Supplementary Materials Figure S1. Whereas, the structures of different compounds are demonstrated in Supplementary Materials Figures S2 and S3.

Table 1. Phytochemical profiling of C. macrocarpa leaves extract by LC-ESI-MS/MS in negative mode.

\begin{tabular}{|c|c|c|c|c|c|}
\hline No. & $\begin{array}{c}\mathrm{Rt} \\
(\min .)\end{array}$ & $\begin{array}{c}{[\mathbf{M}-\mathbf{H}]^{-}} \\
\quad m / z\end{array}$ & $\begin{array}{c}\mathrm{MS}^{2} \\
m / z\end{array}$ & Formula & Identification \\
\hline 1 & 1.17 & 115.000 & $115.081,71.017$ & $\mathrm{C}_{4} \mathrm{H}_{4} \mathrm{O}_{4}$ & Maleic acid \\
\hline 2 & 1.19 & 625.063 & $\begin{array}{c}625.071,429.022,369.071,346.077 \\
301.012\end{array}$ & $\mathrm{C}_{27} \mathrm{H}_{30} \mathrm{O}_{17}$ & $\begin{array}{l}\text { Quercetin-3,4'-O- } \beta- \\
\text { diglucopyranoside }\end{array}$ \\
\hline 3 & 1.21 & 173.046 & $\begin{array}{c}173.044,155.060,140.924,118.587 \\
109.024,93.033\end{array}$ & $\mathrm{C}_{7} \mathrm{H}_{10} \mathrm{O}_{5}$ & (-)-Shikimic acid \\
\hline 4 & 1.22 & 191.056 & $\begin{array}{c}191.054,173.046,133.013,111.044 \\
109.024,93.032\end{array}$ & $\mathrm{C}_{7} \mathrm{H}_{12} \mathrm{O}_{6}$ & D-(-)-Quinic acid \\
\hline 5 & 1.23 & 317.053 & $\begin{array}{c}317.055,281.093,279.106,249.00 \\
191.056\end{array}$ & $\mathrm{C}_{15} \mathrm{H}_{10} \mathrm{O}_{8}$ & Myricetin \\
\hline 6 & 1.59 & 163.038 & $163.039,119.049,91.014$ & $\mathrm{C}_{9} \mathrm{H}_{8} \mathrm{O}_{3}$ & $\begin{array}{l}\text { 3-(4-hydroxyphenyl)prop-2-enoic } \\
\text { acid (p-coumaric acid) }\end{array}$ \\
\hline 7 & 4.10 & 577.172 & $577.156,532.902,269.104$ & $\mathrm{C}_{27} \mathrm{H}_{30} \mathrm{O}_{14}$ & Rhoifolin \\
\hline 8 & 3.45 & 447.188 & $\begin{array}{c}447.180,401.180,301.151,239.127 \\
179.070,151.046,119.035\end{array}$ & $\mathrm{C}_{21} \mathrm{H}_{20} \mathrm{O}_{11}$ & Quercitrin \\
\hline 9 & 4.60 & 417.139 & $417.134,371.169,285.92,209.0788$ & $\mathrm{C}_{20} \mathrm{H}_{18} \mathrm{O}_{10}$ & $\begin{array}{l}\text { Kaempferol-3-O- } \\
\text { alpha-L-arabinoside }\end{array}$ \\
\hline 10 & 4.66 & 461.148 & $461.127,392.912,285.103$ & $\mathrm{C}_{21} \mathrm{H}_{18} \mathrm{O}_{12}$ & Kaempferol-3-O-Glucuronide \\
\hline 11 & 4.80 & 283.096 & $\begin{array}{c}283.090,179.100,171.098,146.956 \\
73.030\end{array}$ & $\mathrm{C}_{16} \mathrm{H}_{12} \mathrm{O}_{5}$ & Acacetin \\
\hline 12 & 4.84 & 289.070 & $\begin{array}{c}289.067,245.084,205.044,187.040 \\
179.046,151.044,123.052\end{array}$ & $\mathrm{C}_{15} \mathrm{H}_{14} \mathrm{O}_{6}$ & Catechin \\
\hline 13 & 5.10 & 183.025 & 183.034 & $\mathrm{C}_{8} \mathrm{H}_{8} \mathrm{O}_{5}$ & 3,4-Dihydroxymandelate \\
\hline 14 & 5.65 & 431.191 & $\begin{array}{l}431.192,383.924,285.213,165.095 \\
159.034,149.047,125.023,119.035\end{array}$ & $\mathrm{C}_{21} \mathrm{H}_{20} \mathrm{O}_{10}$ & $\begin{array}{l}\text { Kaempferol-3-O- } \\
\text { alpha-L-rhamnoside }\end{array}$ \\
\hline 15 & 5.67 & 385.172 & $\begin{array}{c}385.184,248.947,223.131,205.121 \\
190.970,179.053,161.042,149.052 \\
119.035,71.016\end{array}$ & $\mathrm{C}_{17} \mathrm{H}_{22} \mathrm{O}_{10}$ & 1-O- $\beta$-D-glucopyranosyl sinapate \\
\hline 16 & 5.89 & 463.169 & $\begin{array}{c}463.171,403.151,317.103,301.093 \\
208.087,194.033,150.056\end{array}$ & $\mathrm{C}_{21} \mathrm{H}_{20} \mathrm{O}_{12}$ & Myricitrin \\
\hline 17 & 6.01 & 449.108 & $\begin{array}{c}449.102,403.165,381.167 \\
287.03293,269.042,179.002,151.00 \\
107.022\end{array}$ & $\mathrm{C}_{21} \mathrm{H}_{22} \mathrm{O}_{11}$ & Eriodictyol-7-O-glucoside \\
\hline 18 & 6.260 & 609.143 & $\begin{array}{c}609.146,563.234,496.863,285.201 \\
315.043300 .03\end{array}$ & $\mathrm{C}_{27} \mathrm{H}_{30} \mathrm{O}_{16}$ & Luteolin-3', 7-di-O-glucoside \\
\hline 19 & 6.29 & 433.111 & $433.115,271.053,151.036,119.043$ & $\mathrm{C}_{21} \mathrm{H}_{22} \mathrm{O}_{10}$ & Naringenin-7-O-glucoside \\
\hline 20 & 6.69 & 435.092 & $\begin{array}{l}435.084,417.083,389.214,309.053 \\
285.040,178.993,151.042,125.023\end{array}$ & $\mathrm{C}_{21} \mathrm{H}_{24} \mathrm{O}_{10}$ & Phlorizin \\
\hline 21 & 6.79 & 449.102 & $\begin{array}{c}449.114,431.080,342.910,303.049 \\
285.045,276.910,151.00\end{array}$ & $\mathrm{C}_{21} \mathrm{H}_{22} \mathrm{O}_{11}$ & Okanin-4'-O-glucoside \\
\hline 22 & 6.97 & 595.169 & $\begin{array}{c}595.286,548.851,480.844,315.058 \\
287.030\end{array}$ & $\mathrm{C}_{27} \mathrm{H}_{32} \mathrm{O}_{15}$ & Eriodictyol-7-O-rutinoside \\
\hline 23 & 6.99 & 445.171 & $445.169,269.142,112.989$ & $\mathrm{C}_{21} \mathrm{H}_{18} \mathrm{O}_{11}$ & Baicalein-7-O-glucuronide \\
\hline
\end{tabular}


Table 1. Cont.

\begin{tabular}{|c|c|c|c|c|c|}
\hline No. & $\begin{array}{c}\text { Rt } \\
(\min .)\end{array}$ & $\begin{array}{l}{[\mathbf{M}-\mathbf{H}]^{-}} \\
\quad m / z\end{array}$ & $\begin{array}{c}\mathrm{MS}^{2} \\
\mathrm{~m} / \mathrm{z}\end{array}$ & Formula & Identification \\
\hline 24 & 6.98 & 623.063 & $623.208,579.156,532.918,315.036$ & $\mathrm{C}_{28} \mathrm{H}_{32} \mathrm{O}_{16}$ & Isorhamnetin-3-O-rutinoside \\
\hline 25 & 7.15 & 609.521 & $609.144,301.027$ & $\mathrm{C}_{28} \mathrm{H}_{34} \mathrm{O}_{15}$ & Hesperidin \\
\hline 26 & 7.24 & 433.076 & $\begin{array}{l}433.077,389.175,385.201,326.928 \\
301.037,300.030,287.049,271.025\end{array}$ & $\mathrm{C}_{20} \mathrm{H}_{18} \mathrm{O}_{11}$ & Quercetin-3-O-Arabinoside \\
\hline 27 & 7.48 & 477.099 & $\begin{array}{c}477.098,431.222,364.927,331.042 \\
315.041,300.043\end{array}$ & $\mathrm{C}_{22} \mathrm{H}_{22} \mathrm{O}_{12}$ & Isorhamnetin-3-O-glucoside \\
\hline 28 & 7.52 & 507.111 & $\begin{array}{l}507.102,489.186,461.112,345.057 \\
326.930,315.061,286.951,269.121\end{array}$ & $\mathrm{C}_{23} \mathrm{H}_{24} \mathrm{O}_{13}$ & Syringetin-3-O-glucoside \\
\hline 29 & 7.53 & 447.092 & $\begin{array}{c}447.088,401.248,301.034,300.020 \\
285.040,271.026\end{array}$ & $\mathrm{C}_{21} \mathrm{H}_{20} \mathrm{O}_{11}$ & Quercetin-7-O-rhamnoside \\
\hline 30 & 7.57 & 433.079 & $\begin{array}{l}433.080,349.103,326.928,301.036 \\
300.023,269.047,178.993,152.010\end{array}$ & $\mathrm{C}_{20} \mathrm{H}_{18} \mathrm{O}_{11}$ & Quercetin-3-D-xyloside \\
\hline 31 & 7.67 & 405.061 & $\begin{array}{c}\text { 405.093, 369.248, 231.0, 209.066, } \\
191.056,137.020\end{array}$ & $\mathrm{C}_{20} \mathrm{H}_{22} \mathrm{O}_{9}$ & $\begin{array}{l}\text { E-3,4,5'-Trihydroxy-3'- } \\
\text { glucopyranosyl-stilbene }\end{array}$ \\
\hline 32 & 7.70 & 463.088 & $\begin{array}{c}463.119,394.907,354.924,331.054 \\
316.021,301.066,286.934\end{array}$ & $\mathrm{C}_{21} \mathrm{H}_{20} \mathrm{O}_{12}$ & Quercetin-4'-glucoside \\
\hline 33 & 7.87 & 431.097 & $\begin{array}{c}431.092,385.175,341.181,299.023 \\
269.035\end{array}$ & $\mathrm{C}_{21} \mathrm{H}_{20} \mathrm{O}_{10}$ & Apigenin-7-O-glucoside \\
\hline 34 & 7.90 & 447.182 & $447.096,401.202,285.040,112.989$ & $\mathrm{C}_{21} \mathrm{H}_{20} \mathrm{O}_{11}$ & Luteolin-7-O-glucoside \\
\hline 35 & 7.82 & 415.197 & $\begin{array}{c}415.195,369.212,253.165,179.063 \\
161.042,113.020\end{array}$ & $\mathrm{C}_{21} \mathrm{H}_{20} \mathrm{O}_{9}$ & Daidzein-8-C-glucoside \\
\hline 36 & 8.22 & 507.111 & $\begin{array}{c}507.112,462.907,445.205,430.890 \\
394.919,371.207,345.124,329.041 \\
286.932\end{array}$ & $\mathrm{C}_{23} \mathrm{H}_{24} \mathrm{O}_{13}$ & Syringetin-3-O-galactoside \\
\hline 37 & 8.39 & 301.123 & 301.118 & $\mathrm{C}_{16} \mathrm{H}_{14} \mathrm{O}_{6}$ & Hesperetin \\
\hline 38 & 9.57 & 537.083 & $\begin{array}{l}537.021,518.951,493.504,468.105 \\
255.025,248.956,213.018,197.059\end{array}$ & $\mathrm{C}_{30} \mathrm{H}_{18} \mathrm{O}_{10}$ & Cupressuflavone \\
\hline 39 & 9.76 & 301.037 & $\begin{array}{c}\text { 301.036, 255.221, } 243.039,178.997 \\
151.0094\end{array}$ & $\mathrm{C}_{15} \mathrm{H}_{10} \mathrm{O}_{7}$ & Quercetin \\
\hline 40 & 10.08 & 299.056 & $299.055,284.042$ & $\mathrm{C}_{16} \mathrm{H}_{12} \mathrm{O}_{6}$ & $\begin{array}{l}\text { 3,5,7-Trihydroxy-4'-methoxy- } \\
\text { flavone }\end{array}$ \\
\hline 41 & 10.12 & 359.169 & 359.176 & $\mathrm{C}_{18} \mathrm{H}_{16} \mathrm{O}_{8}$ & Rosmarinic acid \\
\hline 42 & 10.23 & 181.047 & $181.049,166.031,138.030,112.986$ & $\mathrm{C}_{9} \mathrm{H}_{10} \mathrm{O}_{4}$ & Syringaldehyde \\
\hline 43 & 10.29 & 271.060 & $\begin{array}{c}271.064,177.022,151.004,119.046 \\
107.020\end{array}$ & $\mathrm{C}_{15} \mathrm{H}_{12} \mathrm{O}_{5}$ & Naringenin \\
\hline 44 & 10.85 & 611.113 & $611.117,565.214,504.961$ & $\mathrm{C}_{28} \mathrm{H}_{36} \mathrm{O}_{15}$ & Neohesperidin dihydrochalcone \\
\hline 45 & 10.96 & 285.039 & $285.038,185.068$ & $\mathrm{C}_{15} \mathrm{H}_{10} \mathrm{O}_{6}$ & Luteolin \\
\hline 46 & 11.23 & 315.109 & $\begin{array}{l}315.169,300.028,297.187,283.022, \\
269.246,246.898,235.177,141.018\end{array}$ & $\mathrm{C}_{16} \mathrm{H}_{12} \mathrm{O}_{7}$ & $\begin{array}{l}3^{\prime} \text {-Methoxy-4',5,7- } \\
\text { trihydroxyflavonol }\end{array}$ \\
\hline 47 & 15.14 & 319.227 & $\begin{array}{c}319.226,318.20,255.209,248.572 \\
164.252\end{array}$ & $\mathrm{C}_{20} \mathrm{H}_{32} \mathrm{O}_{3}$ & Isocupressic acid \\
\hline 48 & 19.60 & 361.238 & $361.237,319.231,301.218,283.165$ & $\mathrm{C}_{22} \mathrm{H}_{34} \mathrm{O}_{4}$ & Acetylisocupressic acid \\
\hline 49 & 23.33 & 305.248 & $305.249,304.280,166.095$ & $\mathrm{C}_{20} \mathrm{H}_{34} \mathrm{O}_{2}$ & Agathadiol \\
\hline
\end{tabular}




\subsubsection{Characterization of Flavonoids Aglycones}

Recognition of different flavonoids aglycons was conducted by an inhouse database to identify luteolin, acacetin, 3, 5, 7-trihydroxy-4'-methoxy flavone, myricetin, quercetin, $3^{\prime}$-methyl quercetin ( $3^{\prime}$-methoxy-4',5,7-trihydroxyflavonol), hesperetin, and naringenin through their pseudomolecular ions at $m / z 285.038,283.090,299.055,317.055,301.036$, $315.169,301.118$, and 271.064 , respectively.

\subsubsection{Characterization of Flavones Glycosides and a Biflavone}

The common neutral loss of 46 Daltons was observed in $\mathrm{MS}^{2}$ fragmentations of flavones glycoside due to loss of $\mathrm{CO}_{2}+\mathrm{H}_{2}$. Luteolin-7-O-glucoside exhibited $[\mathrm{M}-\mathrm{H}]^{-}$ ions at $\mathrm{m} / \mathrm{z}$ 447.096. The neutral loss of 162 Daltons of hexose or glucose moiety was detected at $m / z$ 285.040. The pseudo-molecular ions of Luteolin-3',7-di-O-glucoside at $m / z 609.146$, with loss of neutral ions of two molecules of hexose or glucose (324 Da), was observed by fragment ion of aglycone at $m / z$ 285.201. Apigenin-7-neohesperidoside (rhoifolin) showed pseudo-molecular ions at $\mathrm{m} / \mathrm{z} 577.156$, neutral loss of $\mathrm{CO}_{2}(44 \mathrm{Da})$ indicated at $\mathrm{m} / \mathrm{z}$ 532.902 , and loss of sugar part (308 Da) at $\mathrm{m} / \mathrm{z} 269.104$. The pseudo-molecular ions and the aglycone fragment ions of apigenin-7-O-glucoside were detected at $m / z 431.092$ and 269.035 , respectively. The pseudo-molecular ions of baicalein-7-O- glucuronide (baicalin) were noted at $m / z 445.169$ and the baicalein ions fragment showed at $m / z 269.142$ due to loss of glucuronide moiety. Cupressuflavone or $8,8^{\prime \prime}$ bi-apigenin showed pseudo-molecular ions at $m / z$ 537.021, which were identified according to the reported data [22].

\subsubsection{Characterization of Flavonol Glycosides}

Quercitrin pseudo-molecular ions demonstrated at $\mathrm{m} / \mathrm{z} 447.180$ with loss of rhamnose moiety (146 Da) showing at $m / z 301.151$ and characteristic fragments at $m / z 179.070$ and 151.046. The same loss was recorded for quercetin-7-O-rhamnoside. The $[\mathrm{M}-\mathrm{H}]^{-}$ions were noted at $\mathrm{m} / \mathrm{z} 433.077$ for quercetin-3-O-arabinoside with fragment ions at $\mathrm{m} / \mathrm{z} 389.175$ for loss of $\mathrm{CO}_{2}$ and $\mathrm{m} / \mathrm{z} 301.037$ for loss of pentose moiety (132 Da). The same loss was observed for quercetin-4'-O-glucoside and quercetin-3-O-xyloside with $[\mathrm{M}-\mathrm{H}]^{-}$ions at $\mathrm{m} / \mathrm{z}$ 463.119 and 433.080, respectively, as well as common fragments ions at $m / z 301$ after the loss of hexose or glucose (162 Da) and pentose or xylose (132 Da). The pseudo-molecular ions of quercetin-3, $4^{\prime}$-O- $\beta$-diglucopyranoside were at $m / z$ 625.071, and loss of di-hexose or di-glucose moieties (324 Da), which was noticed due to the existence of mass fragment ions of quercetin at $\mathrm{m} / \mathrm{z}$ 301.012. The pseudo-molecular ions and kaempferol ion fragments of kaempferol-3-O-glucuronide were found at $m / z 461.127$ and 285.103, respectively. Kaempferol-3-O- $\alpha$-L-arabinoside exerted the $[\mathrm{M}-\mathrm{H}]^{-}$ions at $m / z 417.134$ with loss of 132 Daltons of pentose or arabinose fragments at $m / z 285.92$, the $[\mathrm{M}-\mathrm{H}]^{-}$ions of kaempferol-3-O- $\alpha$-L-rhamnoside and myricetin-3-O-rhamnoside (myricitrin) were exhibited at $\mathrm{m} / \mathrm{z} 431.192$ and 463.171 , respectively. The neutral loss of deoxy hexose or rhamnose was found at $m / z 285.213$ and 317.103, respectively. Ion fragments of RDA (retro-DielsAlder) at $m / z 125.023$ and 119.035 showed in $\mathrm{MS}^{2}$ of kaempferol-3-O- $\alpha$-L-rhamnoside. Syringetin-3-O-glucoside and syringetin-3-O-galactoside exerted their pseudo-molecular ions at $m / z 507.102$ and 507.112, respectively, and the loss of neutral ions of hexose (glucose or galactose) moiety (162 Da) was observed at $m / z 345.057$ and 345.124 , respectively. Isorhamnetin-3-O-glucoside showed $[\mathrm{M}-\mathrm{H}]^{-}$ions at $\mathrm{m} / \mathrm{z} 477.098$ with fragment ions of isorhamnetin at $m / z$ 315.041, isorhamnetin-3-O-rutinoside exhibited $[\mathrm{M}-\mathrm{H}]^{-}$ions at $\mathrm{m} / \mathrm{z}$ 623.208 , neutral loss of $\mathrm{CO}_{2}(44 \mathrm{Da}$ ) at $\mathrm{m} / \mathrm{z} 579.156$, and loss of rutinoside (308 Da) at $\mathrm{m} / \mathrm{z}$ 315.036.2.1.4. Characterization of flavanone glycosides

The pseudo-molecular ions of naringenin-7-O-glucoside and eriodictyol-7-O-glucoside were observed at $m / z 433.115$ and 449.102 , respectively, as well as their aglycones at $\mathrm{m} / \mathrm{z}$ 271.053 and 287.032, respectively. The $[\mathrm{M}-\mathrm{H}]^{-}$ions at $\mathrm{m} / \mathrm{z} 595.286$ and the aglycone ion fragments at $m / z 287.030$ of eriodictyol-7-O-rutinoside were observed, and eriodictyol was formed after neutral loss of rutinoside (308 Da). Hesperidin showed pseudo-molecular ions at $m / z 609.144$ and fragment ions at $m / z 301.027$ for hesperetin. 


\subsubsection{Characterization of Isoflavone}

The $[\mathrm{M}-\mathrm{H}]^{-}$ions at $m / z 415.159$ were recognized for daidzein-8-C-glucoside with neutral loss of hexose or glucose (162 Da) at $m / z 253.165$.

\subsubsection{Characterization of Phenolic Compounds}

The $[\mathrm{M}-\mathrm{H}]^{-}$ions at $m / z$ 115.081, 173.044, 191.045, 163.039, 289.067, 183.034, 611.117, 181.049 , and 359.176 corresponded to maleic, shikimic, quinic, p-coumaric acids, catechin, 3,4-dihydroxy mandelate, neohesperidin dihydrochalcone, syringaldehyde, and rosmarinic acids, respectively. Shikimic and quinic acids showed fragment ions at $\mathrm{m} / z 155.060$ and 173.046 due to neutral loss of water. They also shared common ions at $m / z 109$ and 93.

\subsubsection{Characterization of Other Compounds}

Different compounds of 1-O- $\beta$-D-glucopyranosyl sinapate, phlorizin, okanin-4'-Oglucoside, E-3,4,5' -trihydroxy-3' -glucopyranosyl-stilbene, and syringaldehyde exhibited $\mathrm{m} / \mathrm{z}$ at $385.184,435.084,449.114$, and 405.093, respectively. Diterpenoids as isocupressic acid, acetylisocupressic acid, and agathadiol were established through the reported mass spectrometry data [23].

\subsection{Structure Elucidation of Compounds Isolated from C. Macrocarpa Leaves}

\subsubsection{Structure Identification of Hesperidin}

${ }^{1} \mathrm{H}$ NMR (DMSO-d 6 , $\left.500 \mathrm{MHz}\right) \delta_{\mathrm{H}}: 5.52(\mathrm{H}-2 ; 1 \mathrm{H}, \mathrm{dd}, J=12.0,3.5 \mathrm{~Hz}), 2.55(\mathrm{H}-3 \mathrm{axile}$; $1 \mathrm{H}, \mathrm{dd}, J=16.0,4.0 \mathrm{~Hz}), 3.78$ (H-3equatorial; $1 \mathrm{H}, \mathrm{dd}, J=16.0,12.0 \mathrm{~Hz}), 6.12(\mathrm{H}-6 ; 1 \mathrm{H}, \mathrm{d}$, $J=2.5 \mathrm{~Hz}), 6.14(\mathrm{H}-8 ; 1 \mathrm{H}, \mathrm{d}, J=2.5 \mathrm{~Hz}), 6.96\left(\mathrm{H}-2^{\prime} ; 1 \mathrm{H}, \mathrm{d}, J=2.0 \mathrm{~Hz}\right), 6.91\left(\mathrm{H}-5^{\prime} ; 1 \mathrm{H}, \mathrm{d}\right.$, $J=8.5 \mathrm{~Hz}), 6.94\left(\mathrm{H}-6^{\prime} ; 1 \mathrm{H}, \mathrm{dd}, J=2.0,8.5 \mathrm{~Hz}\right), 3.80\left(4^{\prime}-\mathrm{OMe} ; 3 \mathrm{H}, \mathrm{s}\right), 9.12\left(3^{\prime}-\mathrm{OH} ; 1 \mathrm{H}, \mathrm{s}\right), 12.01$ (5-OH; 1H, s), Glucose moiety: $4.97\left(\mathrm{H}-1 "^{\prime \prime} ; 1 \mathrm{H}, \mathrm{d}, J=7.5 \mathrm{~Hz}\right), 3.20-3.60\left(\mathrm{H}-2^{\prime \prime}\right.$ to H-6" $\left.{ }^{\prime \prime}, \mathrm{m}\right)$, Rhamnose moiety: $4.69\left(\mathrm{H}-1^{\prime \prime \prime} ; 1 \mathrm{H}, \mathrm{d}, J=3.0 \mathrm{~Hz}\right), 3.20-3.60\left(\mathrm{H}-2^{\prime \prime \prime}\right.$ to $\left.\mathrm{H}-5^{\prime \prime \prime}, \mathrm{m}\right), 1.09\left(6^{\prime \prime \prime}\right.$; $3 \mathrm{H}, \mathrm{d}, \mathrm{J}=6.0) .{ }^{13} \mathrm{C} \mathrm{NMR}\left(\mathrm{DMSO}-\mathrm{d}_{6}, 125 \mathrm{MHz}\right) \delta: 78.45$ (C-2), 40.89 (C-3), 197.48 (C-4), 163.28 (C-5), 96.82 (C-6), 165.57 (C-7), 95.82 (C-8), 162.51 (C-9), 103.56 (C-10), 131.28 (C-1'), $114.61\left(\mathrm{C}-2^{\prime}\right), 146.93\left(\mathrm{C}-3^{\prime}\right), 148.43\left(\mathrm{C}-4^{\prime}\right), 114.61\left(\mathrm{C}-5^{\prime}\right), 118.39\left(\mathrm{C}-6^{\prime}\right), 56.15(\mathrm{O}-\mathrm{Me})$. Glucose moiety $\left(\mathrm{C}-1^{\prime \prime}\right.$ to $\left.6^{\prime \prime}\right)$ : $99.91,74.5,72.53,70.13,76.68,65.95$. Rhamnose moiety $\left(\mathrm{C}-1^{\prime \prime \prime}\right.$ to $\left.6^{\prime \prime \prime}\right)$ : $101.07,68.84,70.68,76.04,71.28,18.28$. ESI-MS m/z 609.144 [M-H] ${ }^{-}$.

\subsubsection{Structure Elucidation of Eriocitrin}

${ }^{1} \mathrm{H}$ NMR (DMSO-d $\left.6,500 \mathrm{MHz}\right) \delta_{\mathrm{H}}: 5.21(\mathrm{H}-2 ; 1 \mathrm{H}, \mathrm{dd}, J=12.5,3.5 \mathrm{~Hz}), 2.88$ (H-3axile; $1 \mathrm{H}, \mathrm{dd}, J=17.0,3.5 \mathrm{~Hz}$ ), 3.09 (H-3equatorial; $1 \mathrm{H}, \mathrm{dd}, J=17.0,12.5 \mathrm{~Hz}), 6.09(\mathrm{H}-6 ; 1 \mathrm{H}, \mathrm{d}$, $J=2.5 \mathrm{~Hz}), 6.11(\mathrm{H}-8 ; 1 \mathrm{H}, \mathrm{d}, J=2.5 \mathrm{~Hz}), 6.92\left(\mathrm{H}-2^{\prime} ; 1 \mathrm{H}, \mathrm{d}, J=1.5 \mathrm{~Hz}\right), 6.60\left(\mathrm{H}^{-} 5^{\prime} ; 1 \mathrm{H}, \mathrm{d}\right.$, $J=8.5 \mathrm{~Hz}), 6.89\left({\mathrm{H}-6^{\prime}}^{\prime} ; 1 \mathrm{H}, \mathrm{dd}, J=1.5,8.5 \mathrm{~Hz}\right)$, Glucose moiety: $4.94\left(\mathrm{H}-1^{\prime \prime} ; 1 \mathrm{H}, \mathrm{d}, J=7.5 \mathrm{~Hz}\right)$, 3.35-4.25 (H-2" to H-6" $\left.{ }^{\prime \prime}, \mathrm{m}\right)$, Rhamnose moiety: $4.88\left(\mathrm{H}-1^{\prime \prime \prime} ; 1 \mathrm{H}, \mathrm{d}, \mathrm{J}=3.0 \mathrm{~Hz}\right), 3.35-4.25$ $\left(\mathrm{H}-2^{\prime \prime \prime}\right.$ to $\left.\mathrm{H}-5^{\prime \prime \prime}, \mathrm{m}\right), 1.11\left(6^{\prime \prime \prime} ; 3 \mathrm{H}, \mathrm{d}, J=6.0\right) .{ }^{13} \mathrm{C}$ NMR (DMSO-d $\left.6,125 \mathrm{MHz}\right) \delta: 80.9(\mathrm{C}-2)$, 44.89 (C-3), 197.23 (C-4), 163.14 (C-5), 98.12 (C-6), 165.27 (C-7), 96.88 (C-8), 162.59 (C-9), $104.16(\mathrm{C}-10), 130.98\left(\mathrm{C}-1^{\prime}\right), 112.11\left(\mathrm{C}-2^{\prime}\right), 146.53\left(\mathrm{C}-3^{\prime}\right), 148.13\left(\mathrm{C}-4^{\prime}\right), 114.32\left(\mathrm{C}-5^{\prime}\right), 118.13$ $\left(\mathrm{C}-6^{\prime}\right)$. Glucose moiety $\left(\mathrm{C}-1^{\prime \prime}\right.$ to $\left.6^{\prime \prime}\right)$ : 101.12, 74.90, 73.09, 71.70, 77.11, 66.80. Rhamnose moiety $\left(\mathrm{C}-1^{\prime \prime \prime}\right.$ to $\left.6^{\prime \prime \prime}\right)$ : 102.11, 70.32, 72.08, 76.81, 72.40, 18.01. ESI-MS $m / z$ 595.286 [M-H] ${ }^{-}$. Figure 1 represents structures of hesperidin and eriocitrin. 
<smiles>[CH2+]C1O[C](OCC2OC(Oc3cc(O)c4c(c3)OC(c3ccc(OC)c(O)c3)CC4=O)C(O)[C@@H](O)[C@@H]2O)[C@H](O)[C@@H](O)[C@@H]1O</smiles>

Hesperidin

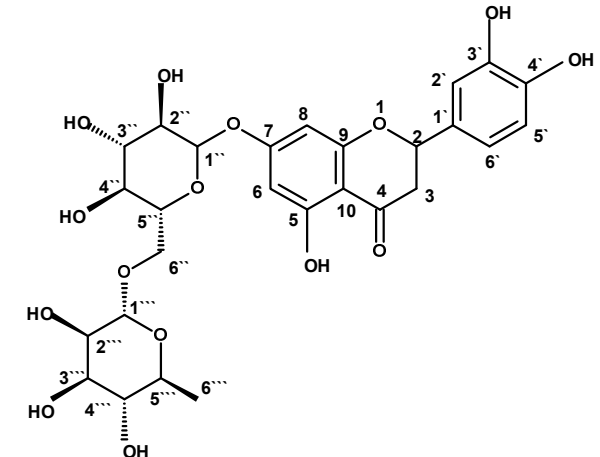

\section{Eriocitrin}

Figure 1. Isolated compounds from C. macrocarpa leaves.

\subsection{Results of In Vitro Antibacterial Activity of C. Macrocarpa Leaves Extracts}

The total methanol extract (TMEL), diethyl ether extract of leaves (DEEL), and methanol extract of defatted leaves (MEDL) exhibited antibacterial effects on the tested MRSA isolates using the agar well-diffusion method. Their minimum inhibitory concentration (MIC) values were detected using the broth microdilution method. The MIC values for the DEEL of C. macrocarpa ranged from 2 to $8 \mu \mathrm{g} / \mathrm{mL}$ (the most potent). However, the MIC values for MEDL and TMEL ranged from 256 to $1024 \mu \mathrm{g} / \mathrm{mL}$ and 1024 to $2048 \mu \mathrm{g} / \mathrm{mL}$, respectively. The MIC values for the positive control (vancomycin) ranged from 0.5 to $4 \mu \mathrm{g} / \mathrm{mL}$.

\subsubsection{Growth Curve Assay}

To determine the effect of DEEL on the growth of MRSA, the growth curves of the tested isolates were analyzed before and after treatment. A significant reduction of $48.78 \%$ in the growth of the tested isolates was observed. A representative example is shown in Figure 2.

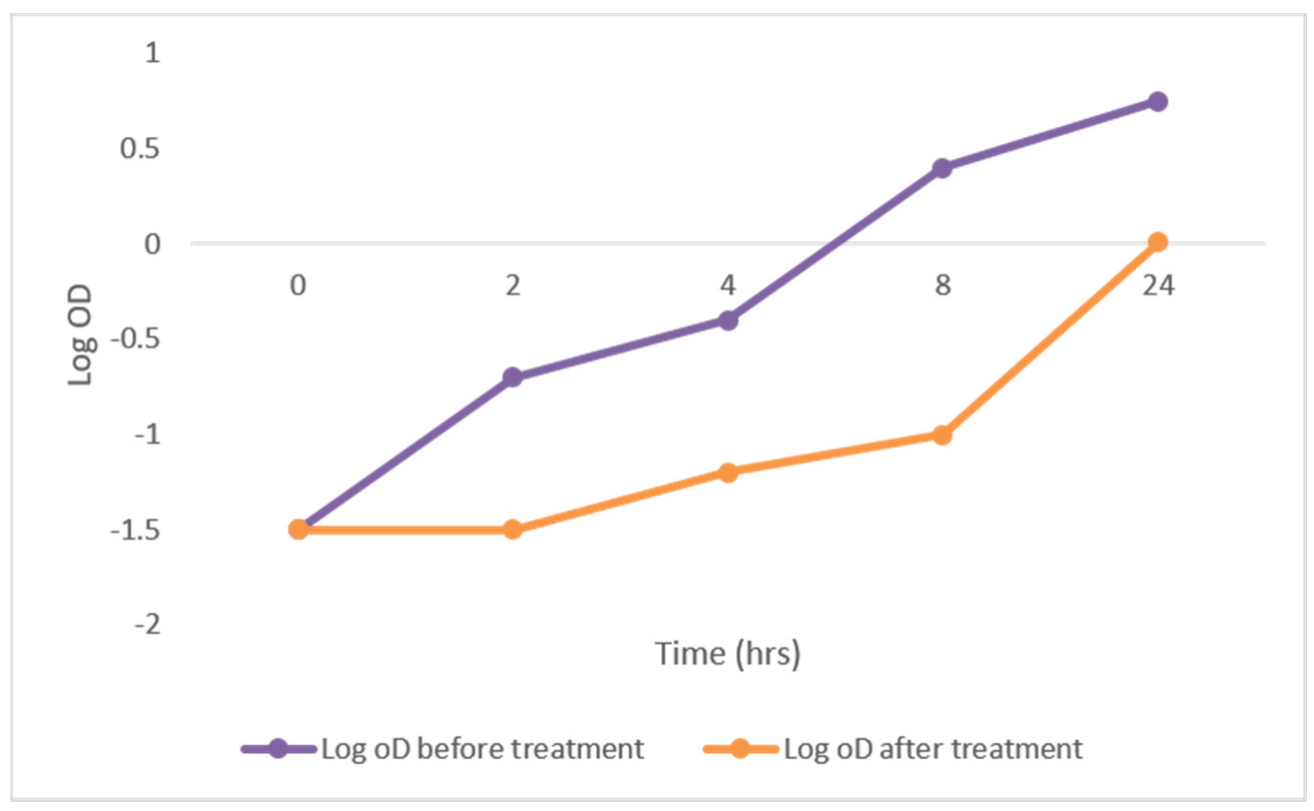

Figure 2. The growth curve of representative MRSA isolates showing a significant reduction in growth after treatment with DEEL. 


\subsubsection{Efflux Assay}

The efflux pump activity is an important mechanism for antibiotic resistance. Herein, the efflux activity of MRSA isolates was determined by evaluating the ability of each isolate to pump out ethidium bromide (EtBr) out of the bacterial cell. The efflux activity of the isolates was categorized into negative, intermediate, and positive using the EtBr cartwheel method. As shown in Table 2, out of 41 MRSA isolates, $12(29.26 \%)$ isolates showed a decrease in their efflux pump activity after treatment with DEEL (i.e., their efflux pump activity was converted from positive to intermediate or negative).

Table 2. Efflux activity of MRSA isolates, measured by EtBr cartwheel method, before and after treatment with DEEL.

\begin{tabular}{ccc}
\hline Efflux Activity & $\begin{array}{c}\text { No. of Isolates before } \\
\text { Treatment }\end{array}$ & $\begin{array}{c}\text { No. of Isolates after } \\
\text { Treatment }\end{array}$ \\
\hline Negative efflux activity & 8 & 21 \\
Intermediate efflux activity & 14 & 13 \\
Positive efflux activity & 19 & 7 \\
\hline
\end{tabular}

\subsubsection{Quantitative RT-PCR}

Quantitative reverse transcription-polymerase chain reaction (qRT-PCR) was utilized to study the effect of DEEL on the efflux activity of MRSA isolates $(n=12)$, which exhibited a decrease in their efflux activity by the cartwheel method. The transcriptional levels of the tested efflux pump genes nor $\mathrm{A}$ and nor $\mathrm{B}$ were remarkably decreased after treatment, with mean values of fold changes ranging from 0.1 to 0.45 (in $66.66 \%$ of clinical isolates) and from 0.08 to 0.39 (in 50\% of clinical isolates), respectively, as shown in Figure 3. The expression level of the nor $\mathrm{C}$ gene showed nonsignificant fold change after treatment.
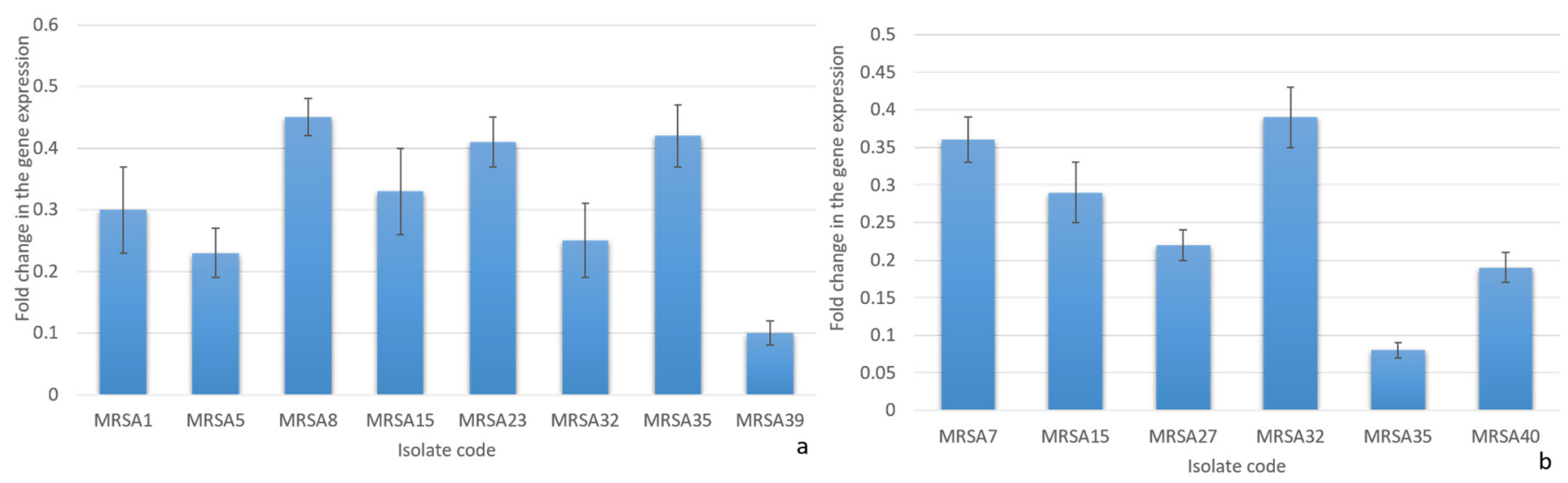

Figure 3. The charts show the fold changes in the transcriptional levels of (a) nor A and (b) norB genes after treatment with the diethyl ether extract of C. macrocarpa leaves.

\subsubsection{Membrane Depolarization Assay}

Membrane depolarization was measured before and after treatment with DEEL using DiBAC4(3), which is a fluorescent indicator dye that can enter the cells when depolarized; thus, membrane depolarization can be studied by recording the fluorescence of this dye using a flow cytometer. We observed nonsignificant change in membrane depolarization after treatment. A representative example is shown in Figure 4. 

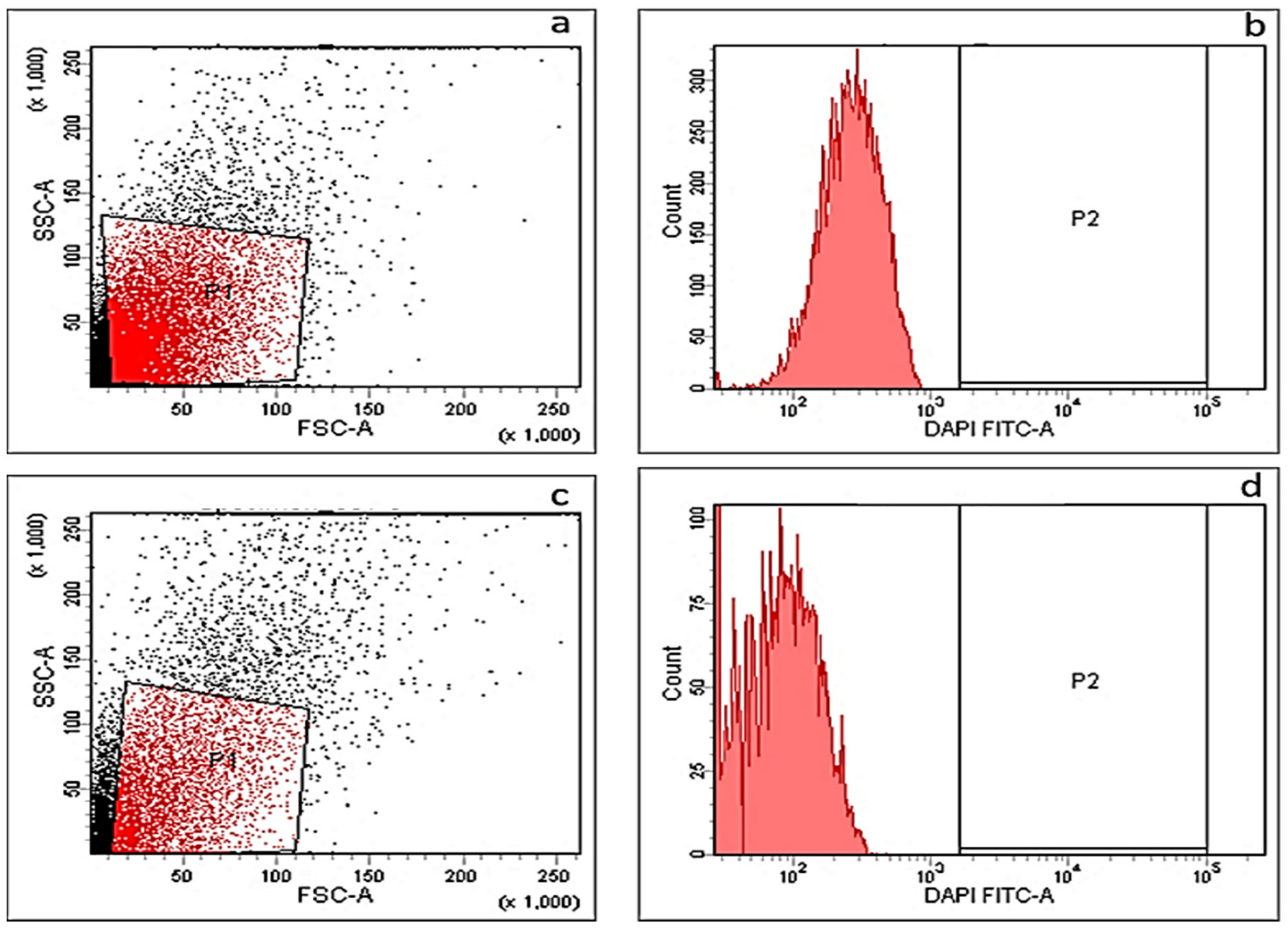

Figure 4. A representative example for MRSA isolates showing nonsignificant change in membrane depolarization detected by flow cytometer. Dot plot (a) and histogram (b) before treatment (showing a fluorescent gap of 52.6\%), dot plot (c) and histogram (d) after treatment (showing a fluorescent gap of $51.3 \%$ ).

2.3.5. Examination of Bacterial Cell Morphology by Scanning Electron Microscope (SEM)

Examination of the cell morphology of MRSA isolates by SEM was carried out to study the ultrastructural changes that occurred after treatment with DEEL. By comparing the treated cells with the untreated ones, we observed that the treated cells were shrinking and there were some degradations of the cell walls, as shown in Figure 5.
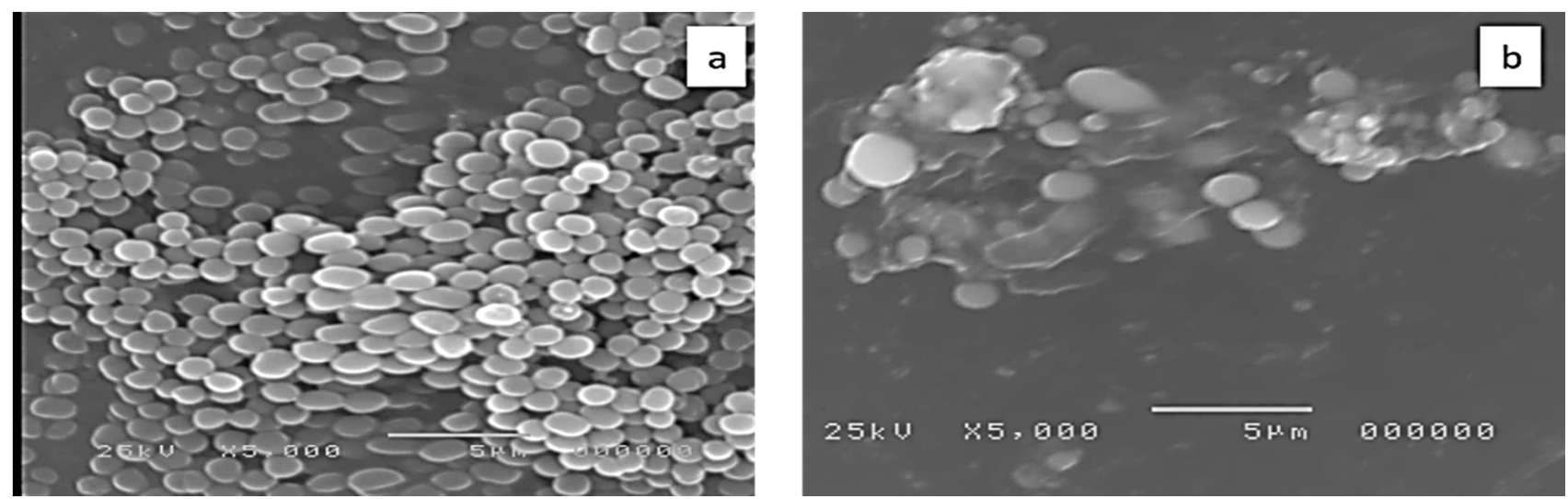

Figure 5. Scanning electron microscope image of a representative MRSA isolate (a) before treatment and (b) after treatment with the diethyl ether extract of C. macrocarpa leaves. 


\subsubsection{Cytotoxicity Assay}

The cytotoxic effect of $C$. macrocarpa DEEL in a human skin fibroblast (HSF) cell line was determined using SRB (Sulforhodamine B) assay [24]. The results revealed that $\mathrm{IC}_{50}$ of $C$. macrocarpa DEEL against HSF cell line was $21.3 \pm 3.41 \mu \mathrm{g} / \mathrm{mL}$ in comparison with doxorubicin as a positive control $\left(\mathrm{IC}_{50}=4.36 \pm 0.52 \mu \mathrm{g} / \mathrm{mL}\right)$.

\subsection{In Vivo Antibacterial Activity Testing}

\subsubsection{Wound Closure Percentage (\%)}

The in vitro antibacterial activity of DEEL was the most potent in comparison with MEDL and TMEL; thus, the antibacterial activity of DEEL was tested in vivo. When DEEL was used to treat wounds, the percentage of wound contraction was significantly higher than in the control group. In addition, when compared to the MRSA-infected group, the infected group treated with DEEL showed a significant increase in wound contraction (Table 3). A significant reduction in the size of the injured area indicated rapid recovery. Figure 6 demonstrates the percentage of the wound area contraction (wound contraction \%), collected on days 7 and 14 .

Table 3. Percentage of wound contraction and area percentage of collagen in different groups.

\begin{tabular}{|c|c|c|c|c|c|}
\hline \multicolumn{6}{|c|}{$\mathbf{X}^{-} \pm \mathbf{S D}$} \\
\hline & GI & GII & GIII & GIV & $p$-Value \\
\hline Wound contraction \% (7 days) & $33.73 \pm 1.32$ & $38 \pm 1.7$ & $14 \pm 2.58$ & $30 \pm 1.82$ & $\begin{array}{l}P 1=0.0001 \\
P 2=0.0001 \\
P 3=0.0001 \\
P 4=0.0001\end{array}$ \\
\hline Wound contraction $\%$ (14 days) & $67.5 \pm 3.03$ & $83.9 \pm 2.28$ & $30.1 \pm 4.28$ & $61 \pm 2.9$ & $\begin{array}{l}P 1=0.0001 \\
P 2=0.0001 \\
P 3=0.0001 \\
P 4=0.0001\end{array}$ \\
\hline Area \% of collagen (7 days) & $39 \pm 2.16$ & $43.8 \pm 1.13$ & $25.3 \pm 2.9$ & $34.1 \pm 1.19$ & $\begin{array}{l}P 1=0.0001 \\
P 2=0.0001 \\
P 3=0.0001 \\
P 4=0.0001\end{array}$ \\
\hline Area \% of collagen (14 days) & $62.1 \pm 2.51$ & $67.9 \pm 1.37$ & $42.4 \pm 3.86$ & $51.4 \pm 2.59$ & $\begin{array}{l}P 1=0.0001 \\
P 2=0.0001 \\
P 3=0.0001 \\
P 4=0.0001\end{array}$ \\
\hline
\end{tabular}

GI: wounded rats treated with normal saline; GII: wounded rats treated with DEEL; GIII: wounded rats infected with MRSA; GIV = wounded rats infected with MRSA and treated with DEEL; $\mathrm{X}^{-}$: mean value; SD: standard deviation; significance: ( $p$-value $\leq$ 0.001). P1: group 2 compared to control; P2: group 3 compared to control; P3: group 4 compared to control; $\mathbf{P 4}$ : group 4 compared to group 3.

\subsubsection{Histological Results (H\&E)}

By day 7, the control group revealed extensive epidermal loss with dermal and epidermal separation occurring on the wound surface. There were inflammatory cells with few fibroblast cells, congested blood vessels, and minimal epidermal growth (Figure 7a). There was epidermal layer regeneration with the less cellular inflammatory response after 14 days, formation of granulation tissue with many cells and some fibers, and moderate collagen deposition (Figure 8a). The group treated with DEEL showed reduced cellular infiltration and regeneration of thin epidermis. Some immature collagen fibers were seen in the dermis after 7 days (Figure $7 \mathrm{~b}$ ). Rats exhibited an incomplete epidermal layer after 14 days. Also, the granulation tissue had newly generated capillaries and higher levels of fibroblast proliferation (Figure 8b). MRSA-treated wound sections after 7 days showed enhanced inflammatory cellular infiltration with necrotic tissue (Figure 7c). By day 14, the granulation tissue was poorly structured, with abundant inflammatory cells, few fibers, and minimal re-epithelialization (Figure 8c). 


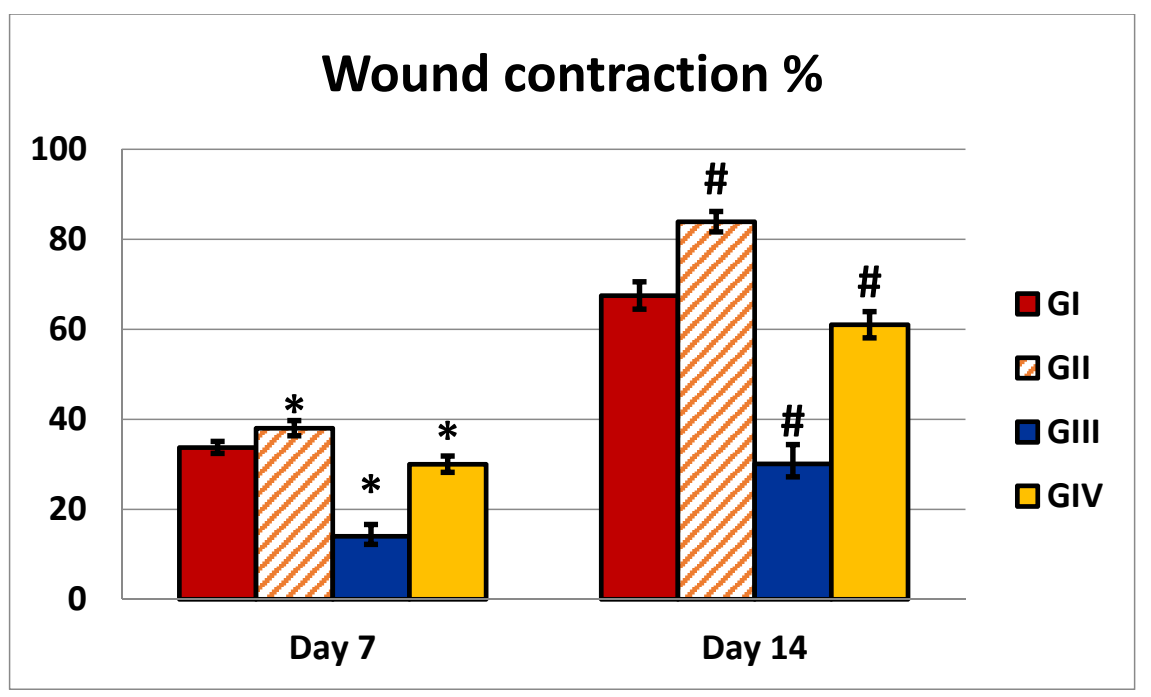

Figure 6. Illustration of an analysis of wounds that were either untreated or treated with DEEL, MRSA, or MRSA + DEEL. Percentage of wound area contraction (wound contraction\%) obtained on days 7 and 14. GI: wounded rats treated with normal saline; GII: wounded rats treated with DEEL; GIII: wounded rats infected with MRSA; GIV: wounded rats infected with MRSA and treated with DEEL of C. macrocarpa. Symbols * and \# indicate that the group is significant in comparison to the control group (GI) at $p \leq 0.001$ after 7 and 14 days, respectively.
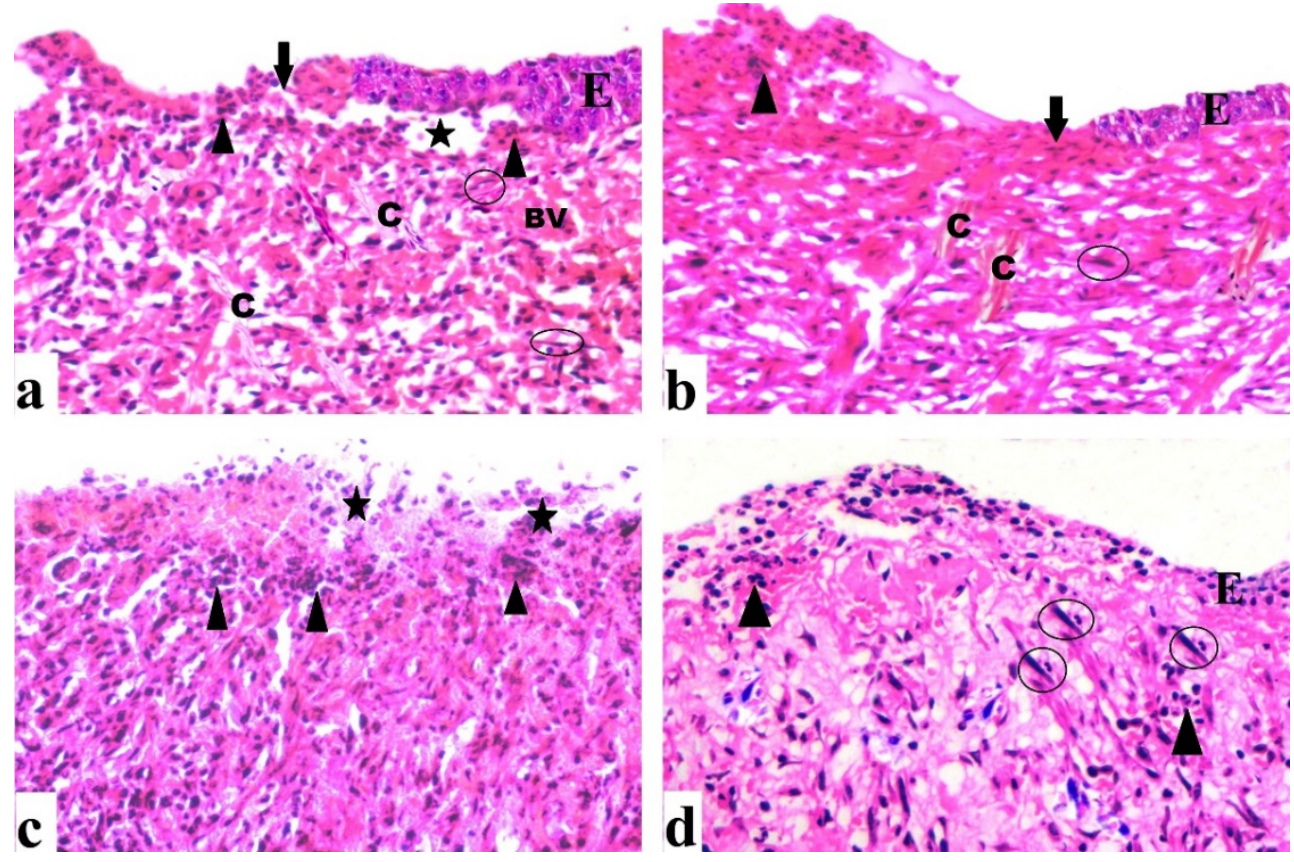

Figure 7. Sections were taken from a skin wound on day 7. (a) An untreated wound demonstrated epidermal loss (arrow), as well as dermal and epidermal separation (star). Inflammatory cells (arrowhead) are apparent, as are several fibroblast cells (circle), as well as congested blood vessels (BV) and regular collagen fibers (C). (b) A wound treated with DEEL showed epidermal loss (arrow), epidermal layer regeneration (E) with inflammatory cells (arrowhead), collagen fibers (C), and several fibroblast cells (circle). (c) An MRSA-infected wound displayed extensive inflammatory cells (arrowhead) as well as necrotic tissue (star). (d) MRSA-infected wound + DEEL treatment showed wound re-epithelialization (E) with significant inflammatory cells (arrowhead), aggregation, and fibroblast proliferation (circle) (H\&E X200). 

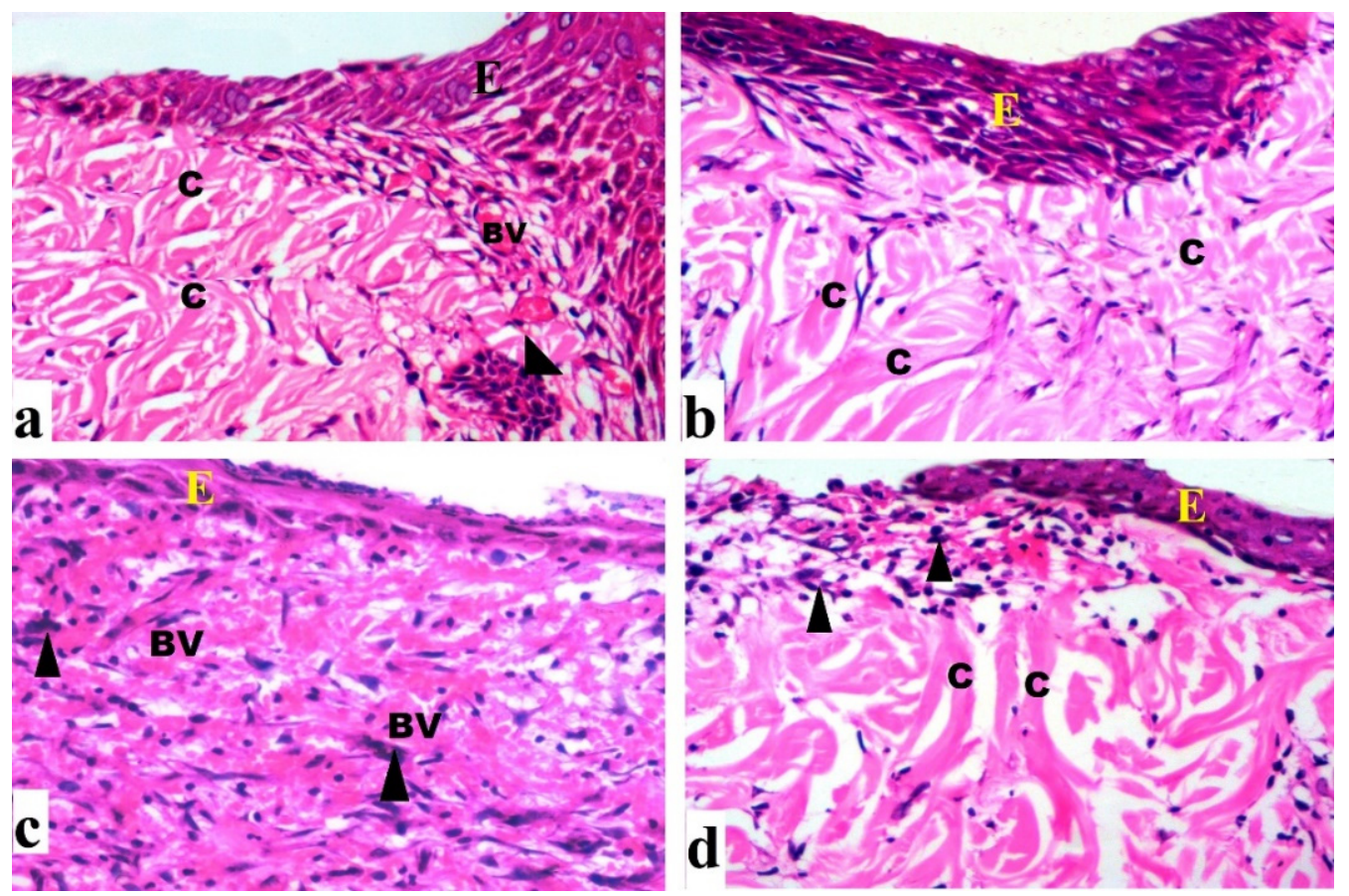

Figure 8. Sections were taken from a skin wound on day 14 (a) An untreated wound indicating aggregation of inflammatory cells (arrowhead), collagen fibers (C) that are regular, partial re-epithelialization (E), and blood capillaries (BV). (b) DEEL-treated wound with newly formed capillaries, increased fibroblast proliferation, dense regular collagen fibers, and re-epithelialization. (c) An MRSA-infected wound displaying poor granulation, numerous inflammatory cells, few fibers, and little re-epithelialization. (d) The wound infected with MRSA and treated with DEEL had an incomplete thin regenerated epidermis and collagen fibers (H\&E X200).

After 7 days of DEEL treatment for MRSA-infected wounds, incomplete re-epithelization with decreased inflammatory cell aggregation was discovered (Figure $7 \mathrm{~d}$ ). There was an incomplete thin regenerated epidermis after 14 days (Figure $8 \mathrm{~d}$ ).

\subsubsection{Mallory Trichrome Stain}

Masson's trichrome sections of the 7-day control group revealed several distributed collagen fibers aligned in various directions (Figure 9a), while the 14-day wound showed moderate collagen fibers accumulating parallel to the epidermis (Figure 10a). In the C. macrocarpa DEEL-treated group, collagen fibers were seen dispersed in numerous orientations (Figure $9 \mathrm{~b}$ ). When compared to the untreated group, there was a considerable increase in thick collagen fibers parallel to the epidermis after 14 days (Figure 10b). In the MRSA-infected group, tiny immature collagen strands were seen in the dermis (Figure 9c). There were scattering irregular collagen fibers after 14 days (Figure 10c). Collagen fibers were found to be thin and uneven after 7 days (Figure $9 \mathrm{~d}$ ) and moderately parallel to the epidermis after 14 days in the infected group treated with DEEL (Figure 10d), which was significantly higher than in the MRSA group (Table 3, Figure 11). 

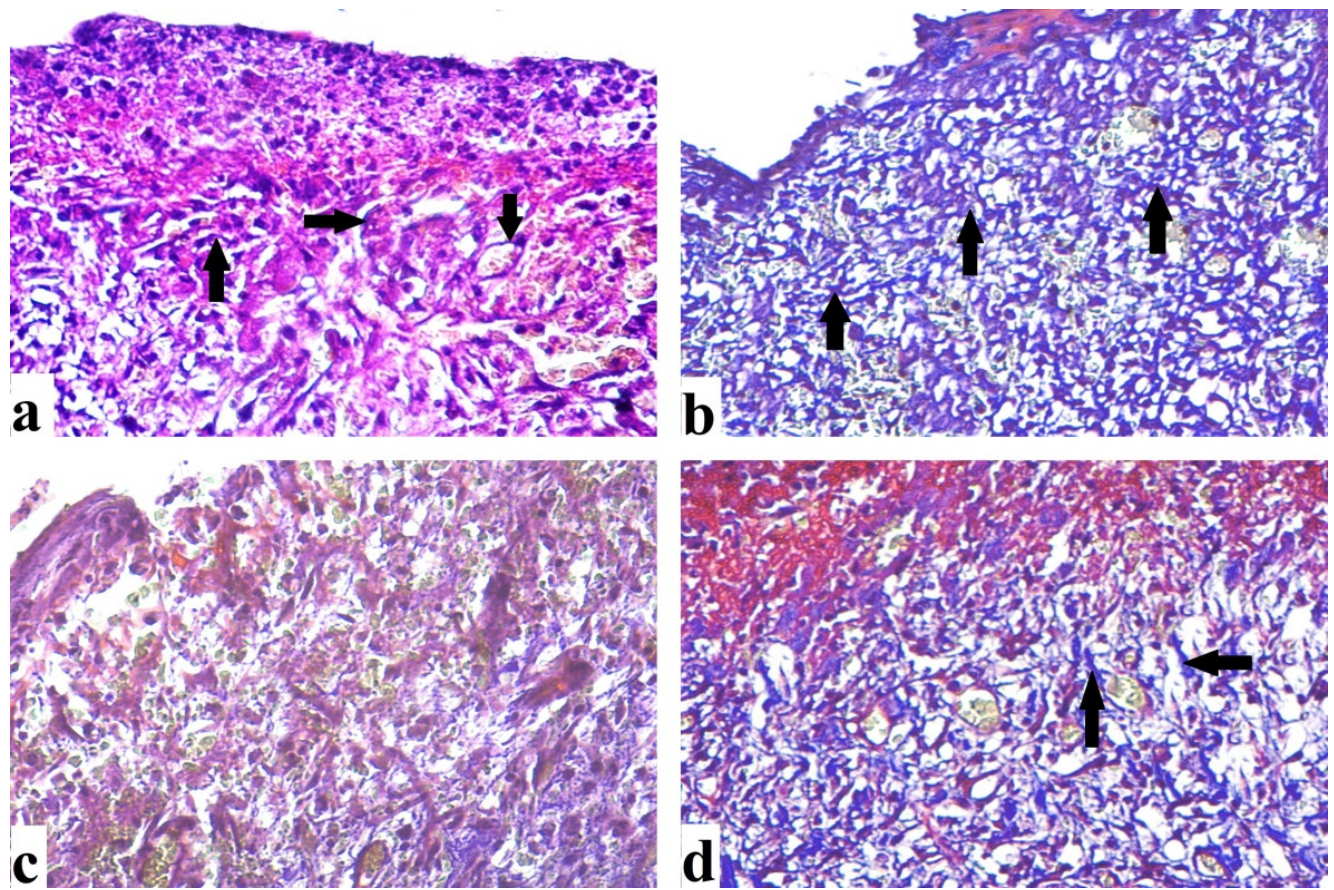

Figure 9. Sections were taken from a skin wound on day 7. (a) Untreated wound exhibited thin collagen fibers (arrow) aligned in different orientations. (b) DEEL-treated wound showed moderate collagen fibers (arrow). (c) An MRSA-infected lesion revealed immature irregular collagen fibers. (d) MRSA-infected lesion with DEEL treatment showed moderate irregular collagen fibers (arrow) (Mallory trichromeX200).

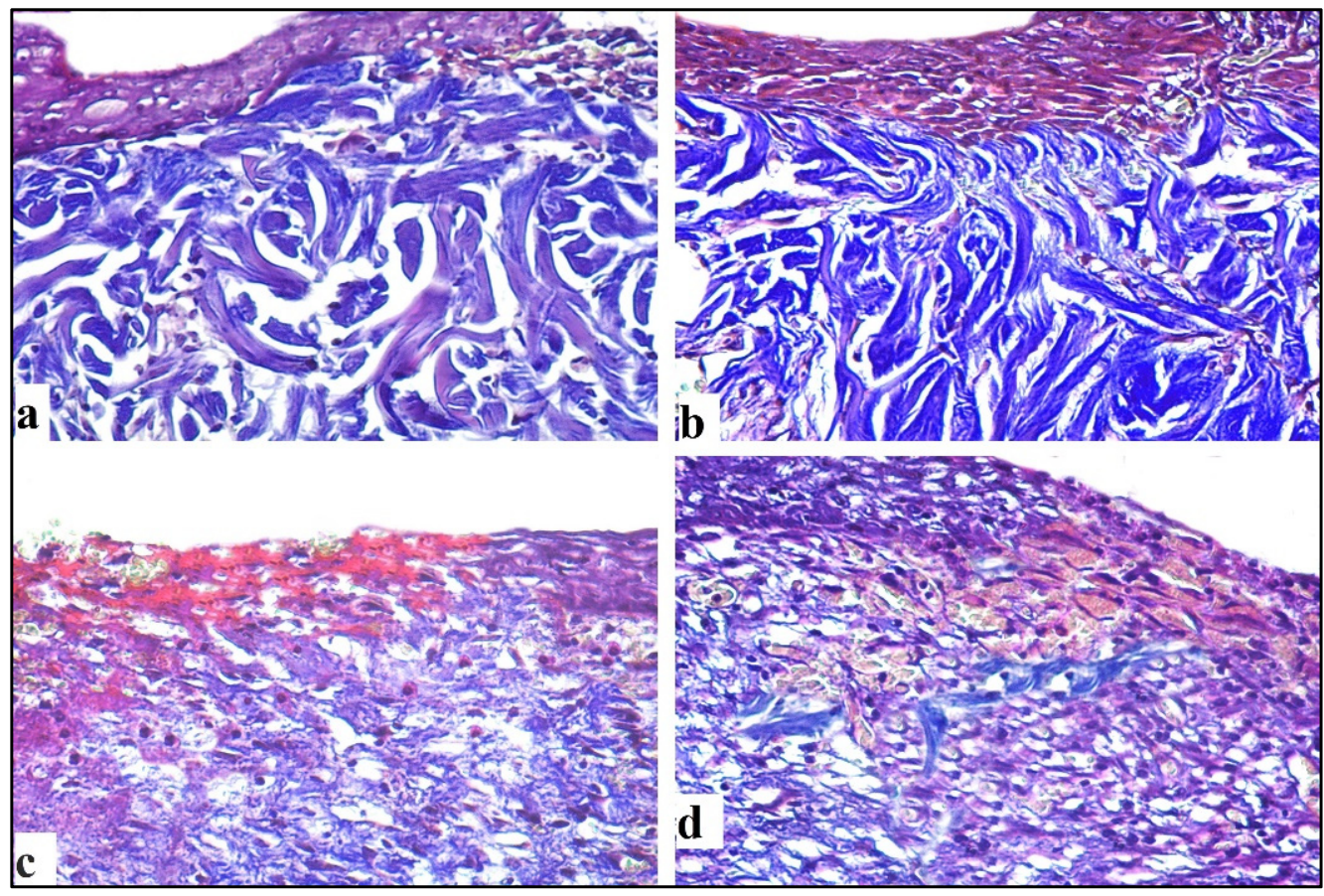

Figure 10. Sections obtained from skin wound on day 14. (a) Untreated wound revealed regular moderate collagen fibers. (b) DEEL-treated wound exhibited thick regular collagen fibers. (c) MRSAinfected wound showed scattering irregular collagen fibers (d) MRSA-infected + DEEL treated wound showed immature irregular collagen fibers (Mallory trichromeX200). 


\section{E-Area \% of Collagen}

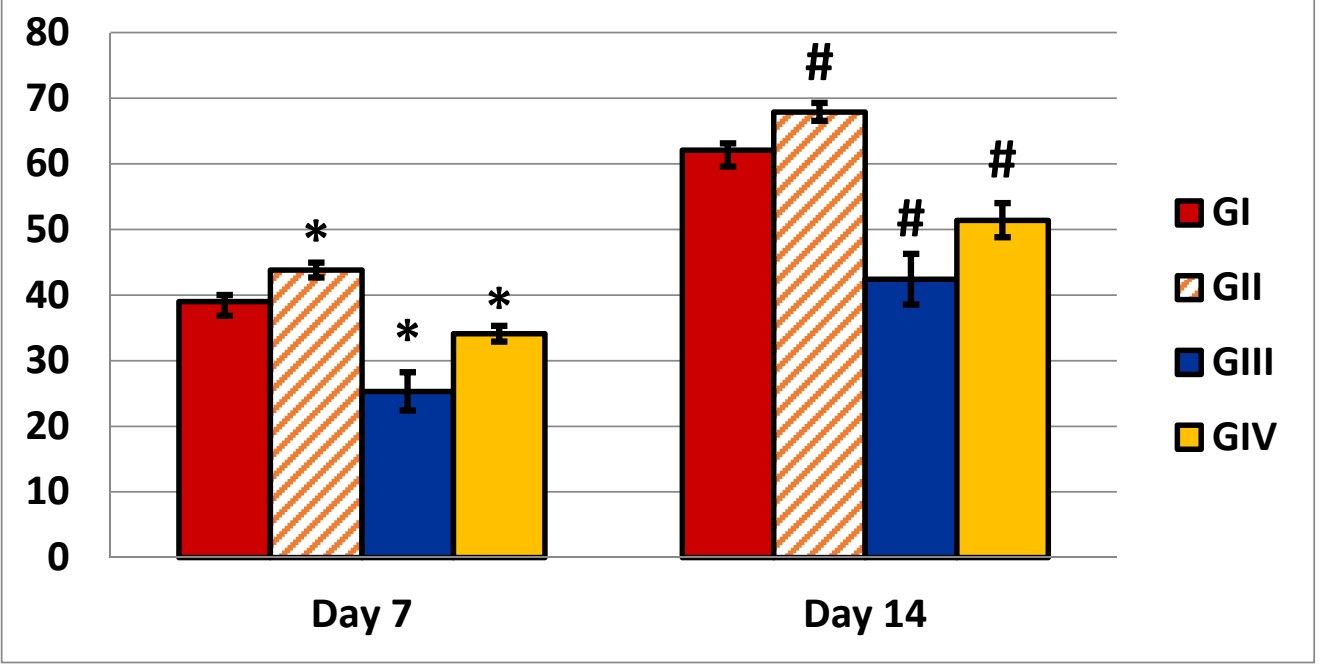

Figure 11. Illustration of an analysis of area \% of collagen that was either untreated or treated with DEEL, MRSA, or MRSA + DEEL. Percentage of collagen (area \%) obtained on days 7 and 14. GI: wounded rats treated with normal saline; GII: wounded rats treated with DEEL; GIII: wounded rats infected with MRSA; GIV: wounded rats infected with MRSA and treated with DEEL. Symbols * and \# indicate that the group is significant in comparison to the control group (GI) at $p \leq 0.001$ after 7 and 14 days, respectively.

\section{Discussion}

LC-ESI-MS/MS is considered a powerful tool to analyze different plant extracts to reveal their phytochemical content based on their molecular mass and mass fragmentation pattern. The analysis of methanol extract of defatted leaves of C. macrocarpa exhibited a tentative identification of 49 compounds of flavones, flavonols, $3^{\prime}, 4^{\prime}, 5^{\prime}$ - trihydroxy flavonols, methoxylated flavonols, flavanones, and their glycosides. Other compounds recognized include: isoflavone e.g., daidzein-8-C-glucoside; biflavonoid e.g., cupressuflavone; labdane diterpenoids e.g., isocupressic acid, acetyl isocupressic acid, and agathadiol; phenolic compounds e.g., shikimic, maleic, quinic acids as well as syringaldehyde, catechin, neohesperidin dihydrochalcone, okanin- $4^{\prime}-O$-glucoside, rosmarinic acid, phlorizin; and stilbenes e.g., E-3,4,5'-trihydroxy-3'-glucopyranosyl-stilbene.

The ${ }^{1} \mathrm{H}-\mathrm{NMR}$ spectrum of the first compound displayed the characteristic signals of a flavanone structure represented by signals at $\delta_{\mathrm{H}}: 2.55(1 \mathrm{H}, \mathrm{dd}, J=16.0,4.0 \mathrm{~Hz}), 3.78(1 \mathrm{H}$, $\mathrm{dd}, J=16.0,12.0 \mathrm{~Hz})$ for C-3 protons and $\delta \mathrm{H} 5.52(1 \mathrm{H}, \mathrm{dd}, J=12.0,3.5 \mathrm{~Hz})$ for H-2. Signals for meta-coupled protons at $\delta 6.12$ and $6.14(\mathrm{~J}=2.5 \mathrm{~Hz})$ are ascribed to $\mathrm{H}-6$ and $\mathrm{H}-8$. An ABX system was displayed by signals resonating at $\delta 6.96(\mathrm{~d}, J=2.0 \mathrm{~Hz})$ for $\mathrm{H}-2^{\prime}, 6.91$ $(\mathrm{d}, J=8.5 \mathrm{~Hz})$ for $\mathrm{H}-5^{\prime \prime}$, and $6.94(\mathrm{dd}, J=2.0,8.5 \mathrm{~Hz})$ for $\mathrm{H}-6^{\prime \prime}$. A methoxy group at C-4' was compatible with a single signal at $\delta 3.80$ integrated for three protons. Sugar protons ranged from 3.20 to $3.60 \mathrm{ppm}(\mathrm{m})$, while signals for two anomeric protons resonating at $\delta 4.97(\mathrm{~d}, J=7.5 \mathrm{~Hz})$ and $4.69(\mathrm{~d}, J=3.0 \mathrm{~Hz})$ suggested the presence of $\beta$-D-glucose and $\alpha$-L-rhamnose. The ${ }^{1} \mathrm{H}-\mathrm{NMR}$ established the presence of two hydroxyls, resonating at $\delta 9.12,12.01$ for $\mathrm{OH}$ at $\mathrm{C}-3^{\prime}$ and $\mathrm{C}-5$, respectively.

The ${ }^{13} \mathrm{C}$-NMR spectra revealed the presence of flavanone glycoside by signals resonating at $\delta_{C} 78.45$ and 40.89 , which could be ascribed to C-2 and C-3, respectively. Glucose carbons resonated at $\delta 99.91,74.5,72.53,70.13,76.68$, and 65.95 , while rhamnose carbons $\left(1^{\prime \prime \prime}\right.$ to $\left.5^{\prime \prime \prime}\right)$ resonated at $\delta 101.07,68.84,70.68,76.04$, and 71.28 , as well as C- $6^{\prime \prime \prime}$ at $\delta 18.28$. The ESI/MS presented ions at $m / z 609.144[\mathrm{M}-\mathrm{H}]^{-}$for $\mathrm{C}_{28} \mathrm{H}_{34} \mathrm{O}_{15}$, which is in agreement 
with the determined structure as hesperidin $[25,26]$. This is the first report for isolation of hesperidin from C. macrocarpa leaves.

The ${ }^{1} \mathrm{H}-\mathrm{NMR}$ spectrum of the second compound established the characteristic signals for the flavanone structure as represented by signals at $\delta_{\mathrm{H}} 2.88(1 \mathrm{H}, \mathrm{dd}, J=17.0,3.5 \mathrm{~Hz})$ and $3.09 \mathrm{ppm}(1 \mathrm{H}, \mathrm{dd}, J=17.0,12.5 \mathrm{~Hz})$ for the two geminal $\mathrm{C}-3$ protons beside the signal at $\delta 5.21(1 \mathrm{H}, \mathrm{dd}, \mathrm{J}=12.5,3.5)$ for $\mathrm{H}-2$. Signals for meta-coupled protons at $\delta 6.09$ and $6.11(\mathrm{~J}=2.5 \mathrm{~Hz})$ were consistent with H-6 and H-8 assignment, respectively. Signals at $\delta 6.92(\mathrm{~d}, J=1.5 \mathrm{~Hz})$ for $\mathrm{H}-2^{\prime}, 6.89(\mathrm{dd}, J=1.5,8.5 \mathrm{~Hz})$ for $\mathrm{H}-6^{\prime}$, and $6.60(\mathrm{~d}, J=8.5 \mathrm{~Hz})$ for $\mathrm{H}-5^{\prime}$ displayed an ABX system. Multiple signals for sugar protons resonated from $\delta 3.35$ to 4.25 . Signals resonating at $\delta 4.88(\mathrm{~d}, J=3.0 \mathrm{~Hz})$ and $4.94(\mathrm{~d}, J=7.5 \mathrm{~Hz})$ suggested the presence of $\alpha$-L-rhamnose and $\beta$-D-glucose. The ${ }^{13} \mathrm{C}-\mathrm{NMR}$ data revealed the presence of flavanone glycoside. Signals resonating at $\delta_{C} 80.9$ and 44.9 could be ascribed to $C-2$ and C-3, respectively. Glucose carbons resonated at $\delta 101.12,74.90,73.09,71.70,77.11$, and 66.80, while rhamnose carbons resonated at $\delta 102.11,70.32,72.08,76.81,72.40$, and 18.01 . The ESI/MS of the compound showed ions at $m / z 595.286[\mathrm{M}-\mathrm{H}]^{-}$for $\mathrm{C}_{27} \mathrm{H}_{32} \mathrm{O}_{15}$, which is in concordance with the determined structure. All spectral data of this compound are consistent with those reported for eriodictioside or eriodictyol- 7-O-rutinoside (eriocitrin) [27,28]. This is the first time reporting the isolation of eriodictioside from $C$. macrocarpa leaves.

The global spread of multi-drug resistance among pathogenic bacteria has stimulated enormous interest in research for novel antimicrobial agents from plants [29]. In the current study, we observed that the diethyl ether extract of $C$. macrocarpa leaves showed higher antibacterial activity against MRSA isolates than the methanol extract of defatted leaves and total methanol extract.

The diethyl ether extract was previously investigated phytochemically by GC/MS analysis, which unveiled its phytochemical profile [10]. The major active constituents found in this fraction were abietane diterpenes derivatives, e.g., ferruginol, 13-methyl-13-vinylpodocarp-7-en-3-one- and 13-isopropyl-podocarpa-6, and 13-diene, as well as monoterpenes which constitute the essential oil part of the diethyl ether extract, e.g., $\gamma$-terpinene, $\alpha$ phellandrene, $\alpha$-terpinene, camphor, limonene, trans-ocimene, camphene, citronellol, and citronellyl butyrate. [10] Abietane diterpenoids have exerted valuable bioactivity against bacteria and fungias; they were reported to be effective against Mycobacterium tuberculosis and Staphylococcus aureus, including methicillin-resistant (MRSA) strains and biofilm infection of $S$. aureus [30]. Ferruginol is an aromatic abietane and was reported to exert significant antibacterial effects against Bacillus subtilis, Staphylococcus aureus, and Streptococcus durans [31]. The active constituents in the essential oil of leaves and branchlets exhibited antimicrobial effects e.g., $\gamma$-terpinene [32], $\alpha$-phellandrene [33], $\alpha$-terpinene [34], camphor, and limonene [35].

The bacterial growth curve has been commonly used to evaluate the effect of antibacterial agents over a given time (usually $24 \mathrm{hrs)} \mathrm{[36].} \mathrm{A} \mathrm{significant} \mathrm{reduction} \mathrm{in} \mathrm{the} \mathrm{growth}$ of $48.78 \%$ of the tested isolates was observed after treatment with DEEL. This may indicate that the antibacterial activity of this extract was associated with a variety of physiological factors in the bacterial cell [37], which needs further studies to explore the potential impact of the extract on different cellular events.

Efflux pumps are proteins located in the bacterial cell membrane. Their function is to transfer toxins out of the cell; thus, they confer cellular protection from many toxins. Efflux pumps are considered the main mechanism of resistance to many antibiotics [38]. We observed that $29.26 \%$ of MRSA isolates exhibited a decrease in efflux pump activity after treatment with DEEL. S. aureus expresses many efflux pumps that help confer antibiotic resistance. The most common efflux pumps of $S$. aureus are encoded by $\operatorname{nor} \mathrm{A}, \operatorname{nor} \mathrm{B}$, and nor C [39]. For further explanation of the impact of DEEL on the efflux activity of the twelve MRSA isolates that exhibited a decrease in the efflux pump activity by the EtBr cartwheel method, qRT-PCR was used. We observed that $66.66 \%$ (8 out of 12 isolates) and $50 \%$ (6 out of 12 isolates) showed a significant down expression of nor A and nor B genes, respectively, after treatment. A nonsignificant change in the expression level of the nor $\mathrm{C}$ gene was 
observed after treatment. Many researchers have focused on the detection of efflux pump inhibitors from plant sources [38,40-42]. Such efflux inhibitors from a natural source can be used to decrease antibiotic resistance among pathogenic bacteria [38].

The bacterial cell membrane is a major target for many new antibacterial compounds and dissipation of the bacterial cell membrane potential may be the sole mechanism of action, or it can contribute to the potency of the studied antibacterial compound [43]. Thus, we examined the membrane depolarization in MRSA isolates before and after treatment with DEEL. A nonsignificant change in membrane depolarization after treatment was observed.

Scanning electron microscopy is commonly used in microbiological research to study the ultrastructural changes that occur in the morphology of bacterial cells after treatment with antimicrobial agents [44]. Therefore, SEM was utilized in the current study as it can produce images for the external cell morphology and surface characteristics with higher resolution compared to the light microscope. We observed that the bacterial cells after treatment with DEEL shrunk with degradation to the cell walls.

Wound healing is a vital biological process that happens when a variety of cell types and their products interact synergistically [45]. Bacterial infection, however, can inhibit and impede natural wound healing. S. aureus is a dangerous bacterium that can cause wound infection [46]. From the in vitro antibacterial study, it was found that diethyl ether of $C$. macrocarpa leaves exhibited the best activity; as a result, we investigated its efficacy on a rat model with an MRSA-infected cutaneous wound.

According to a histological examination, 7 days of untreated wounds showed cellular infiltration with thin collagen fibers. After 14 days, there was a reduction in inflammatory cells, thick collagen deposition, and partial re-epithelialization. Our findings were consistent with those of reported data [47].

Our in vivo study results demonstrated that treatment of DEEL of C. macrocarpa was highly significant against cutaneous wound infection in a rat model. It significantly improved wound contracture and healing. Furthermore, it appeared to improve healing by regenerating the epidermis, maturing granulation tissue, and reducing inflammatory cell infiltration associated with collagen fibers deposition when compared to with the MRSAinfected group. These findings were consistent with those that showed that $C$. macrocarpa leaves inhibited the production of proinflammatory cytokines such as PGE2, TNF-a, IL-1b, and IL-6, hence preventing chronic inflammation and enhancing wound healing [9]. The histopathology finding was also consistent with previous findings by Saad et al. in 2017 [5].

MRSA-infected wounds were shown to have an abundance of inflammatory cells, few collagen fibers, little re-epithelialization, and inadequate granulation tissue, as well as a significant reduction in wound contracture as compared with untreated wounds. According to researchers, S. aureus infection causes cutaneous collagen breakdown, which leads to impaired granulation tissue and, as a result, delayed wound healing [48].

The cell viability SRB assay of DEEL against HSF normal cell line was performed. $\mathrm{IC}_{50}$ of DEEL was $21.3 \pm 3.41 \mu \mathrm{g} / \mathrm{mL}$ in comparison with doxorubicin $\left(\mathrm{IC}_{50}=4.36 \pm 0.52 \mu \mathrm{g} / \mathrm{mL}\right.$ ) as a positive control.

Finally, our results provided light on the reusing of $C$. macrocarpa as an efficient and novel topical therapy to treat MRSA. The current study laid the groundwork for future clinical trials as an antibacterial drug to treat skin infections caused by pathogenic MRSA isolates.

\section{Materials and Methods}

\subsection{Plant Material}

Cupressus macrocarpa leaves with branchlets were collected and dried at room temperature in May 2017 from a nursery at Shebin El-Kom, El-Menoufia Governorate. The plant was recognized by Prof. Mohammed Ibrahim Fotoh, Professor of Ornamental Horticulture and Landscape Design. A voucher sample (PG00411) was deposited at Herbarium of the Department of Pharmacognosy, Faculty of Pharmacy, Tanta University. The different 
extracts were carried out by the cold maceration method. The dried leaves with branchlets ( $2 \mathrm{~kg}$ ) of C. macrocarpa were extracted first with $4 \mathrm{~L}$ of petroleum ether for 3 days, three times ( $4 \mathrm{~L} \times 3$ times), and then with $5 \mathrm{~L}$ of $95 \%$ methanol three times $(5 \mathrm{~L} \times 3$ times) for 3 days each. Both extracts were evaporated under reduced pressure. The yield was 7.5\% and $6.2 \%$ for petroleum ether and methanol extracts, respectively.

\subsection{Method of Isolation of Flavonoids}

The dried methanol extract was suspended in a mixture of methanol and water (2:1). The formed suspension was successively extracted with dichloromethane, ethyl acetate, and $n$-butanol. Extracts of methylene chloride, ethyl acetate, and $n$-butanol were completely evaporated under a vacuum at $40{ }^{\circ} \mathrm{C}$ to obtain a dry residue of each solvent. Ethyl acetate (4 g) was applied to a silica gel column chromatography (160 g, $\phi 5 \times 30 \mathrm{~cm})$, and fractions of $50 \mathrm{~mL}$ volume were collected. Elution was undertaken with a successive gradient of $\mathrm{CH}_{2} \mathrm{Cl}_{2}-\mathrm{MeOH}$ mixtures of increasing polarities. The $\mathrm{CH}_{2} \mathrm{Cl}_{2}-\mathrm{MeOH}$ (85:15) eluates, A21 (325 mg) and A23 (245 mg), were chromatographed to column chromatography using silica gel $(20 \mathrm{~g}, \phi 2 \times 15 \mathrm{~cm})$. The collected fractions were $15 \mathrm{~mL}$ each, which were eluted successively with an increasing gradient of the polarity of $\mathrm{CH}_{2} \mathrm{Cl}_{2} / \mathrm{MeOH}$ mixture. Subfraction B19 eluted from A21 sub-column at (90:10) of $\mathrm{CH}_{2} \mathrm{Cl}_{2}$ : methanol was purified on Sephadex LH-20 (15 g, $\phi, 2 \times 12 \mathrm{~cm})$ with $\mathrm{MeOH}$ to afford the first compound (10 $\mathrm{mg})$. Subfraction $\mathrm{C} 15$ eluted from $\mathrm{A} 23$ sub-column at (88:12) of $\mathrm{CH}_{2} \mathrm{Cl}_{2}$ : methanol was applied to isocratic CC $(10 \mathrm{~g}, \phi, 1.2 \times 10 \mathrm{~cm})$ on silica gel with $\mathrm{CHCl}_{3}$ : $\mathrm{MeOH}(95: 5)$ to give a yellowish residue; this residue was subjected to Sephadex LH-20 $(15 \mathrm{~g}, \phi, 2 \times 10 \mathrm{~cm})$ with $\mathrm{MeOH}$ to give the second compound $(8 \mathrm{mg})$. Structure determination was undertaken by A JEOL ECA-500 II NMR spectrometer, which was used to record NMR spectra. NMR samples were analyzed at $500 \mathrm{MHz}$ for ${ }^{1} \mathrm{H}$ and $125 \mathrm{MHz}$ for ${ }^{13} \mathrm{C}$. Samples were dissolved in DMSO-d 6 .

\subsection{LC-ESI-MS/MS Analysis of C. Macrocarpa Leaves Extract}

\subsubsection{Preparation of Plant Sample}

A total of $100 \mathrm{~g}$ of dried leaves powder was defatted by maceration in petroleum ether at room temperature. After complete exhaustion, methanol was added to the powder, and after extraction, methanol was evaporated under a vacuum at $40^{\circ} \mathrm{C}$. A weighed portion of the residue $(50 \mathrm{mg}$ ) was reconstituted in a $1 \mathrm{~mL}$ solution of deionized water, methanol, and acetonitrile (50: 25: 25). The dissolved sample was vortexed for $2 \mathrm{~min}$, ultra-sonicated for $10 \mathrm{~min}$, and centrifuged for another $10 \mathrm{~min}$ at $1000 \mathrm{rpm}$. Dilution was carried out with the reconstitution solvent to inject $10 \mu \mathrm{L}$ of the sample solution at a concentration of $1 \mu \mathrm{g} / \mu \mathrm{L}$.

\subsubsection{LC-ESI-MS/MS Method}

Compounds in the crude extracts were identified by Proteomics and Metabolomics Unit, Children's Cancer Hospital (57357), Basic Research Department, Cairo, Egypt. The crude extracts were reconstituted in DI-Water, methanol, and acetonitrile (50:25:25) and analyzed by LC-ESI-MS/MS using ExionLC ${ }^{\mathrm{TM}}$ AD UPLC, coupled with TripleTOF 5600+ Time-of-Flight Tandem Mass Spectrometer (AB SCIEX). The injection concentration was $1 \mu \mathrm{g} / \mathrm{mL}$ and volume $10 \mu \mathrm{L}$. The column used was the XSelect HSS T3 XP column (Waters, $2.1 \mathrm{~mm} \times 150 \mathrm{~mm}$ ) at $40{ }^{\circ} \mathrm{C}$. The flow rate was $300 \mu \mathrm{L} / \mathrm{min}$ of the mixture of $1 \%$ methanol in $5 \mathrm{mM}$ ammonium formate buffer ( $\mathrm{pH}$ 8) (A) and acetonitrile (B). Gradient elution was used as the following: isocratic elution with $90 \%$ of solvent $\mathrm{A}$ and $10 \%$ of acetonitrile for $1 \mathrm{~min}$, gradient elution with 90 to $10 \%$ solvent A and $10 \%$ to $90 \%$ of acetonitrile for $20 \mathrm{~min}, 90 \%$ of acetonitrile for $4 \mathrm{~min}$, and then returned to the initial condition $(10 \%$ of acetonitrile) for $3 \mathrm{~min}$. Mass spectra were acquired under negative-ion mode in an information-dependent mode with an automatic switch between a full scan $(50-1000 \mathrm{~m} / \mathrm{z})$ and up to 15 information-dependent MS/MS scans. The intensity threshold to trigger an MS/MS scan was set to $10^{4} \mathrm{ppm}$. The MS1 and MS2 tolerance values were 0.01 and 0.05 mass units, respectively. The maximum ion monitoring time was $3000 \mathrm{~ms}$. The ion 
spray voltage was set to $4500 \mathrm{~V}$, the turbo spray temperature $500{ }^{\circ} \mathrm{C}$, nebulizer gas $45 \mathrm{psi}$, heater gas $45 \mathrm{psi}$, and declustering potential $80 \mathrm{~V}$, and normalized collision energy $35 \mathrm{~V}$. The dynamic exclusion was applied using a setting of 10 seconds. Raw data files were loaded into MS-DIAL 3.52 (http:/ / prime.psc.riken.jp/) [49] for data-independent MS/MS deconvolution. Compounds were identified with $>70 \%$ probability using a MS1 and MS2 tolerance of 0.2 mass unit to be accepted as positive identifications. PeakView was used for feature or peaks extraction from total ion chromatogram (TIC). Based on that, the features should have a signal-to-noise ratio greater than 5 (non-targeted analysis) as well as features intensities of the sample-to-blank ratio as greater than 3 .

\subsection{Materials and Methods of Antibacterial Study of C. Macrocarpa Leaves Extracts \\ 4.4.1. Bacterial Isolates and Chemicals}

A total of 41 MRSA isolates were collected from clinical samples from different departments of Tanta University Hospital. The clinical samples were originally taken from patients for proper diagnosis and treatment, thus ethical approval was not required. The bacterial isolates were viewed microscopically and were identified by standard biochemical tests (MacFaddin, 1976). MRSA isolates were detected phenotypically, using the cefoxitin disk diffusion $(30 \mu \mathrm{g})$ method [50] and genotypically, using PCR for detection of the mecA gene [51]. Staphylococcus aureus (ATCC 29231) was used as a reference strain.

\subsubsection{In vitro Antibacterial Activity Testing}

Three different portions of $100 \mathrm{~g}$ of leaves and branchlets dried powder, were macerated at room temperature. The first portion was macerated in diethyl ethyl ether (DEEL), the second portion in light petroleum ether tell exhaustion (defatted leaves) then methanol (MEDL), and the third portion in methanol (TMEL) only. Each extract was evaporated under a vacuum to obtain three different residues. The in vitro antibacterial activity of the obtained residues was carried out by agar well diffusion method [52]. Approximately $100 \mu \mathrm{L}$ of each bacterial suspension was distributed on the surface of plates containing Muller-Hilton agar. Then, five wells were punched off using a cork-borer and each well was filled with $100 \mu \mathrm{L}(1024 \mu \mathrm{g} / \mathrm{mL})$ of each of the following: DEEL, MEDL, and TMEL (reconstituted in DMSO). The plates were incubated at $37^{\circ} \mathrm{C}$ for $24 \mathrm{~h}$ using DMSO as a negative control and vancomycin $(30 \mu \mathrm{g} / \mathrm{mL})$ as a positive control.

\section{Determination of MICs}

The MIC values were determined for DEEL, MEDL, and TMEL by broth microdilution method using DMSO for dilutions [50]. A well containing a bacterial suspension without the extract (a positive control) and another well containing broth without any bacteria (a negative control) were incorporated in each microtitration plate. The MIC values of the extracts were identified for each bacterial isolate as the lowest extract concentration, which showed complete inhibition of bacterial growth (i.e., absence of turbidity). The subsequent tests (in vitro and in vivo) were accomplished before and after treatment of MRSA isolates with sub-inhibitory concentrations (i.e., $0.5 \mathrm{MIC}$ values ranged from 1 to $4 \mu \mathrm{g} / \mathrm{mL}$ ) of DEEL (the most potent).

\section{Growth Curve Assay}

This assay was conducted to assess the impact of DEEL on the growth of MRSA (at $0.5 \mathrm{MIC}$ values ranging from 1 to $4 \mu \mathrm{g} / \mathrm{mL}$ ) [53]. The optical density (OD) of MRSA (before and after treatment) was measured at $620 \mathrm{~nm}$ using $1800 \mathrm{UV}-$ Vis spectrophotometer (SHIMADZU, Kyoto, Japan) at time intervals of 0, 2, 4, 6, 8, and $24 \mathrm{~h}$. The growth curves were constructed by plotting $\log \mathrm{OD}_{620}$ versus the sampling time (h).

\section{Efflux Assay}

This assay was conducted before and after treatment with DEEL (at 0.5 MIC values ranging from 1 to $4 \mu \mathrm{g} / \mathrm{mL}$ ), using the EtBr cartwheel method [39,54], and the reference 
strain was used as a negative control. Each bacterial suspension was swabbed as redial lines onto tryptic soy agar (TSA) plates supplied with concentrations of EtBr ranging from 0.5 to $2.5 \mathrm{mg} / \mathrm{L}$, and they were incubated for $16 \mathrm{hrs}$ at $37^{\circ} \mathrm{C}$. The minimum concentration of EtBr resulted in the production of fluorescence by the bacterial isolates and was recorded using a UV-Vis transilluminator (SHIMADZU, Kyoto, Japan). MRSA isolates were classified based on the detected minimum concentration of EtBr. Isolates emitting fluorescence at $0.5 \mathrm{mg} / \mathrm{L}$ $\mathrm{EtBr}$ were considered to have negative efflux activity; isolates emitting fluorescence at 1-2.0 $\mathrm{mg} / \mathrm{L} \mathrm{EtBr}$ were considered to have intermediate efflux activity, and isolates emitting fluorescence at $2.5 \mathrm{mg} / \mathrm{L} \mathrm{EtBr}$ were considered to have positive efflux activity.

\section{QRT-PCR}

The expression levels of the efflux pump genes (nor $\mathrm{A}$, nor $\mathrm{B}$, and nor $\mathrm{C}$ ) [55] were detected after treatment with DEEL using qRT-PCR. Briefly, after centrifugation of the overnight cultures of MRSA isolates (with and without treatment), the pellets were immediately utilized for total RNA extraction using the Purelink ${ }^{\circledR}$ RNA Mini Kit (Thermo SCIENTIFIC, Waltham, USA) as described by the manufacturer. The purified RNA was rapidly retrotranscribed into cDNA using a power cDNA synthesis kit (iNtRON Biotechnology, Korea) as recommended by the manufacturer. qRT-PCR was accomplished using the Rotor-Gene Q 5plex machine (Qiagen, Hilden, Germany). The qRT-PCR was conducted to calculate the fold changes in the expression of the tested genes using the housekeeping gene 16S rRNA as an endogenous control [51]. The used primers are listed in Table S1. The relative levels of target gene expression were quantified using the $2^{-\Delta \Delta \mathrm{Ct}}$ method (the expression levels of isolates before treatment were set to be 1) [56]. Only genes with $\geq$ two-fold changes (either increased or decreased) were regarded to be statistically significant [57].

\section{Membrane Depolarization Assay}

This assay was performed after staining the bacterial cells (before and after treatment with DEEL using DiBAC4(3), a fluorescent molecular probe) as previously described [58]. The utilized instrument to analyze the cellular staining was the FACSVerse flow cytometer (BD Biosciences, Franklin Lakes, NJ, USA).

\section{Examination of Morphology by SEM}

The cell morphology of MRSA isolates was examined by SEM (Hitachi, Chiyoda, Japan) before and after treatment with DEEL as described by McDowell and Trump [59].

\subsubsection{In Vivo Antibacterial Activity Testing}

In this experiment, forty adult male albino rats weighing between 180 and $220 \mathrm{~g}$ were used. Animals were obtained from the animal house at Menoufia University's Faculty of Medicine and were acclimatized under laboratory settings for one week before the experiment began. Rats were housed in a safe standard habitat at room temperature, with an unrestricted meal and water supply. Four groups, each with ten animals, were constructed. After removing the dorsal hair and sterilizing with $10 \%$ povidone-iodine, a full-thickness excision wound measuring $1.5 \times 1.5 \mathrm{~cm}$ was created on the mid-back of each animal.

1. Group I (control group): wounds were treated daily with $20 \%$ DMSO in normal saline $(0.9 \%(w / v) \mathrm{NaCl}$ freshly prepared).

2. Group II (C. macrocarpa group): wounds were treated daily with a thin layer of DEEL in $20 \%$ DMSO in normal saline (1 mg/mL, $1 \mathrm{~mm}$ thickness).

3. Group III (MRSA-infected group): MRSA was used to contaminate the wounds with $10 \mu \mathrm{L}$ of the bacterial suspension $\left(10^{6} \mathrm{CFU}\right)$.

4. Group VI (MRSA+ C. macrocarpa treated group): wounds were infected with MRSA and treated daily with a thin coating of DEEL in $20 \%$ DMSO in normal saline $(1 \mathrm{mg} / \mathrm{mL}, 1 \mathrm{~mm}$ thickness). 
Histological Study

On day 7, five rats from each group were sacrificed, and the remaining animals were slaughtered on day 14 . The skin wound tissues were immediately extracted and handled in $10 \%$ formal saline for histological examinations. Tissues fixed in paraffin were sliced into $5 \mu \mathrm{m}$ thick sections and submitted to Haematoxylin and Eosin (H\&E) stain and Mallory's trichrome stain for collagen fibers procedures [60].

\section{Morphometric Analysis}

Ten different isolated fields from each segment were measured for quantitative evaluation using a Leica DML B2/11888111 microscope equipped with a Leica DFC450 camera (Leica Microsystems, Wetzlar, Germany). Image J software version K1.45 was used to estimate the measured variance. H\&E and Mallory's trichrome were used to collect data. Wound closure $\%=$ (initial wound size-wound at the time of taking the image)/initial wound size) $\times 100$ [61] mean area percentage of collagen fibers with sections stained with Mallory's Trichrome $(\times 200)$.

\subsection{Chemical Reagents and Cell Line}

Methanol, formic acid, and sodium hydroxide for PH adjustment (Fisher Scientific, Loughborough, UK); vancomycin, acetonitrile, and ammonium formate (SigmaAldrich, Darmstadt, Germany); water (Milli-Q) (Millipore, Burlington, VT, USA). Sigma Aldrich provided sulfoxide (DMSO), doxorubicin, Sulfo-Rhod-amine-B stain (SRB) (3-(4,5dimethylthiazol-2-yl)-2,5-diphenyltetrazolium bromide), and all the analytical grade solvents used in this study. HSF cell line was obtained from Nawah Scientific Inc. (Mokatam, Cairo, Egypt).

\subsection{Cytotoxicity Assay}

Cell viability was assessed by SRB assay. In 96-well plates, aliquots of $100 \mu \mathrm{L}$ cell suspension $\left(5 \times 10^{3}\right.$ cells) were incubated in a complete medium for $24 \mathrm{~h}$. Another aliquot of $100 \mu \mathrm{L}$ media containing the extract at various concentrations was used to treat the cells. After $72 \mathrm{hrs}$ of exposure to the extract, the cells were fixed by replacing the medium with $150 \mu \mathrm{L}$ of $10 \%$ trichloroacetic acid (TCA) and incubating for one hour at $4{ }^{\circ} \mathrm{C}$. After removing the TCA solution, the cells were washed five times with distilled water. Aliquots of $70 \mu \mathrm{L}$ of SRB solution ( 0.4 percent $w / v)$ were added and incubated at room temperature for $10 \mathrm{~min}$ in the dark. Plates were washed three times with $1 \%$ acetic acid and air-dried overnight. The absorbance was measured at $540 \mathrm{~nm}$ using a BMG LABTECH ${ }^{\circledR}$ - FLUOstar Omega microplate reader (BMG LABTECH, Ortenberg, Germany) after $150 \mu \mathrm{L}$ of TRIS $(10 \mathrm{mM})$ was added to dissolve protein-bound SRB stain [24].

\subsection{Statistical Analysis}

All the conducted tests were carried out in triplicate. Data are presented as means \pm standard deviation (SD) using SPSS software version 26 (IBM Corp., New York, NY, USA). The varied parameters acquired from separate groups were compared using $t$-test (ANOVA) and Bonferroni's post hoc test to establish statistical significance. $p<0.001$ was used to determine the statistical significance of the data.

\section{Conclusions}

The elucidation of 49 different compounds was carried out tentatively for the defatted methanol extract of C. macrocarpa leaves using LC-ESI-MS/MS. Isolation of two flavanones, hesperidin and eriocitrin, was conducted for the first time. DEEL demonstrated the best antibacterial activity against $48.78 \%$ of MRSA clinical isolates. It significantly reduced the efflux activity by $29.26 \%$ as well as downregulating the expression of nor $\mathrm{A}$ and nor $\mathrm{B}$ genes in $66.66 \%$ and $50 \%$ of the clinical isolates, respectively, and significantly affected the bacterial cell morphology. The in vivo study results exhibited that topical treatment with DEEL is highly efficient against cutaneous wound infections in a rat model., which 
significantly improved wound healing through regenerating the epidermis, maturing granulation tissue, and reducing inflammatory cell infiltration, in comparison with the MRSA-infected group. The in vivo study on rats showed no adverse reactions in all rates during the 14 days. Generally, from the obtained results, we can conclude that DEEL may provide a promising source to develop a curative antibacterial drug against the problematic MRSA bacteria.

Supplementary Materials: The following are available online at https://www.mdpi.com/article/ 10.3390/antibiotics10080890/s1, Figure S1: total ion chromatogram (TIC) of methanol extract of C. macrocarpa leaves (negative mode). Figure S2 (a,b,c,d): structure of flavonoids and their glycosides identified in C. macrocarpa leaves and methanol extract of leaves. Figure S3: compounds tentatively identified of C. macrocarpa leaves by LC-ESI-MS/MS (Glu = glucose). Table S1: The sequences of utilized primers.

Author Contributions: Conceptualization, N.G.M.A.; formal analysis, W.A.N., E.E., H.E.-H., and S.A.E.-S.; funding acquisition, N.G.M.A., E.I.E., and T.A.E.-M.; investigation, E.I.E.; methodology, W.A.N., E.E., H.E.-H., and S.A.E.-S.; project administration, N.A.; resources, N.A.; software, N.A.; supervision, T.A.E.-M.; validation, E.I.E.; visualization, N.G.M.A.; writing-original draft, W.A.N., E.E., H.E.-H., and S.A.E.-S.; writing-review \& editing, W.A.N., E.E., H.E.-H., S.A.E.-S., and T.A.E.-M. All authors have read and agreed to the published version of the manuscript.

Funding: This work was funded by the Deanship of Scientific Research (DSR) at Princess Nourah bint Abdulrahman University, Riyadh, Saudi Arabia through the Research Groups Program grant no. (RGP-1441-0028).

Institutional Review Board Statement: The study was conducted according to the guidelines of the Institutional Animal Care and Use Committee (IACUC) at Faculty of Science, Menoufia University. The protocol code was (MUFM-F-HI-1-21) and the approval date was 4 February 2021. The animal should not be overcome by a non-justified burden. Animals should be restrained and transported humanly. Taking care of the animal during the peri-operative time with no negligence was done without mutilation of the animal. The animal was not euthanatized unless required, with balanced ecosystem care for the animal's husbandry. Care for the infectious, enzootic, epizootic, and zoonotic diseases and informing for the serious diseases was provided. Disposal of animal's bodies should be in a proper manner.

Data Availability Statement: The data presented in this study are available on request.

Acknowledgments: This work was funded by the Deanship of Scientific Research (DSR) at Princess Nourah bint Abdulrahman University, Riyadh, Saudi Arabia through the Research Groups Program grant no. (RGP-1441-0028). The authors, therefore, gratefully acknowledge the DSR technical and financial support.

Conflicts of Interest: The authors declare no conflict of interest.

\section{References}

1. Little, D.P. Evolution and circumscription of the true cypresses (Cupressaceae: Cupressus). Syst. Bot. 2006, 31, 461-480. [CrossRef]

2. Cupressus macrocarpa I International Plant Names Index. Available online: https://www.ipni.org/n/60451557-2 (accessed on 6 May 2021).

3. Cupressus macrocarpa (Monterey cypress) Description. Available online: https://www.conifers.org/cu/Cupressus_macrocarpa.php (accessed on 6 May 2021).

4. Thukral, S.K.; Singh, S.; Sharma, S.K. Pharmacognostical standardization of leaves of Cupressus macrocarpa Hartweg. ex Gordon. J. Appl. Pharm. Sci. 2014, 4, 71-74. [CrossRef]

5. Saad, A.M.; Mohammed, M.M.D.; Ghareeb, M.A.; Ahmed, W.S.; Farid, M.A. Chemical Composition and Antimicrobial Activity of the Essential Oil of the Leaves of Cupressus macrocarpa Hartweg. ex Gordon Article Info Abstract. J. Appl. Pharm. Sci. 2017, 7, 207-212. [CrossRef]

6. Salem, M.Z.M.; Elansary, H.O.; Ali, H.M.; El-Settawy, A.A.; Elshikh, M.S.; Abdel-Salam, E.M.; Skalicka-Woźniak, K. Bioactivity of essential oils extracted from Cupressus macrocarpa branchlets and Corymbia citriodora leaves grown in Egypt. BMC Complement. Altern. Med. 2018, 18, 23. [CrossRef]

7. Cool, L.G. Sesquiterpenes from Cupressus macrocarpa foliage. Phytochemistry 2005, 66, 249-260. [CrossRef] [PubMed]

8. Al-Sayed, E.; Ke, T.Y.; Hwang, T.L.; Chen, S.R.; Korinek, M.; Chen, S.L.; Cheng, Y. Bin Cytotoxic and anti-inflammatory effects of lignans and diterpenes from Cupressus macrocarpa. Bioorg. Med. Chem. Lett. 2020, 30, 127127. [CrossRef] [PubMed] 
9. Al-Sayed, E.; Gad, H.A.; El-Shazly, M.; Abdel-Daim, M.M.; Nasser Singab, A. Anti-inflammatory and analgesic activities of cupressuflavone from Cupressus macrocarpa: Impact on pro-inflammatory mediators. Drug Dev. Res. 2018, 79, 22-28. [CrossRef] [PubMed]

10. Al-Ashmawy, G.M.; El-Sherbeni, S.A. Protective effect of Cupressus macrocarpa and Dioon edule against gentamicin-induced nephrotoxicity in rats. J. Pharm. Pharmacogn. Res. 2020, 8, 434-448.

11. Fahed, L.; Khoury, M.; Stien, D.; Ouaini, N.; Eparvier, V.; El Beyrouthy, M. Essential Oils Composition and Antimicrobial Activity of Six Conifers Harvested in Lebanon. Chem. Biodivers. 2017, 14, e1600235. [CrossRef]

12. Maleki, S.J.; Crespo, J.F.; Cabanillas, B. Anti-inflammatory effects of flavonoids. Food Chem. 2019, 299, 125124. [CrossRef]

13. Lv, D.; Cheng, X.; Tang, L.; Jiang, M. The cardioprotective effect of total flavonoids on myocardial ischemia/reperfusion in rats. Biomed. Pharmacother. 2017, 88, 277-284. [CrossRef]

14. Sak, K. Cytotoxicity of dietary flavonoids on different human cancer types. Pharmacogn. Rev. 2014, 8, 122-146. [CrossRef]

15. Cushnie, T.P.T.; Lamb, A.J. Antimicrobial activity of flavonoids. Int. J. Antimicrob. Agents 2005, 26, 343-356. [CrossRef]

16. Kumar, S.; Pandey, A.K. Chemistry and biological activities of flavonoids: An overview. Sci. World J. 2013, 2013, 162750. [CrossRef]

17. Techniques of Flavonoid Identification (1982 Edition) I Open Library. Available online: https://openlibrary.org/books/OL37903 91M/Techniques_of_flavonoid_identification (accessed on 11 May 2021).

18. Pollitt, E.J.G.; Szkuta, P.T.; Burns, N.; Foster, S.J. Staphylococcus aureus infection dynamics. PLoS Pathog. 2018, 14, e1007112. [CrossRef] [PubMed]

19. Klein, E.Y.; Mojica, N.; Jiang, W.; Cosgrove, S.E.; Septimus, E.; Morgan, D.J.; Laxminarayan, R. Trends in Methicillin-Resistant Staphylococcus aureus Hospitalizations in the United States, 2010-2014. Clin. Infect. Dis. 2017, 65, 1921-1923. [CrossRef] [PubMed]

20. El-Baz, A.M.; Yahya, G.; Mansour, B.; El-Sokkary, M.M.A.; Alshaman, R.; Alattar, A.; El-Ganiny, A.M. The Link between Occurrence of Class I Integron and Acquired Aminoglycoside Resistance in Clinical MRSA Isolates. Antibiotics 2021, 10, 488. [CrossRef]

21. Chassagne, F.; Samarakoon, T.; Porras, G.; Lyles, J.T.; Dettweiler, M.; Marquez, L.; Salam, A.M.; Shabih, S.; Farrokhi, D.R.; Quave, C.L. A Systematic Review of Plants with Antibacterial Activities: A Taxonomic and Phylogenetic Perspective. Front. Pharmacol. 2021, 11, 2069. [CrossRef]

22. Sani, A.A.; Alemika, T.E. Isolation and characterisation of cupressuflavone from the leaves of Lophira lanceolata. Artic. J. Pharm. Bioresour. 2011, 7, 14-18. [CrossRef]

23. Aguiar, G.P.; Crevelin, E.J.; Dias, H.J.; Ambrósio, S.R.; Bastos, J.K.; Heleno, V.C.G.; Vessecchi, R.; Crotti, A.E.M. Electrospray ionization tandem mass spectrometry of labdane-type acid diterpenes. J. Mass Spectrom. 2018, 53, 1086-1096. [CrossRef]

24. Skehan, P.; Storeng, R.; Scudiero, D.; Monks, A.; Mcmahon, J.; Vistica, D.; Warren, J.T.; Bokesch, H.; Kenney, S.; Boyd, M.R. New colorimetric cytotoxicity assay for anticancer-drug screening. J. Natl. Cancer Inst. 1990, 82, 1107-1112. [CrossRef]

25. Maltese, F.; Erkelens, C.; Kooy, F.; van der Choi, Y.H.; Verpoorte, R. Identification of natural epimeric flavanone glycosides by NMR spectroscopy. Food Chem. 2009, 116, 575-579. [CrossRef]

26. Jadeja, Y.S.; Kapadiya, K.M.; Jebaliya, H.J.; Shah, A.K.; Khunt, R.C. Dihedral angle study in Hesperidin using NMR Spectroscopy. Magn. Reson. Chem. 2017, 55, 589-594. [CrossRef]

27. Miyake, Y.; Yamamoto, K.; Osawa, T. Isolation of Eriocitrin(Eriodictyol 7-Rutinoside) from Lemon Fruit(Citrus limon Burm. f.) and Its Antioxidative Activity. Food Sci. Technol. Int. Tokyo 1997, 3, 84-89. [CrossRef]

28. Nogata, Y.; Ohta, H.; Ishii, T.; Sekiya, K. Isolation of eriocitrin (eriodictyol 7-O-rutinoside) as an arachidonate lipoxygenase inhibitor from Lumie fruit (Citrus lumia) and its distribution in Citrus species. J. Sci. Food Agric. 2007, 87, 82-89. [CrossRef]

29. Aslam, B.; Wang, W.; Arshad, M.I.; Khurshid, M.; Muzammil, S.; Rasool, M.H.; Nisar, M.A.; Alvi, R.F.; Aslam, M.A.; Qamar, M.U.; et al. Antibiotic resistance: A rundown of a global crisis. Infect. Drug Resist. 2018, 11, 1645-1658. [CrossRef]

30. Neto, I.; Faustino, C.; Rijo, P. Antimicrobial abietane diterpenoids against resistant bacteria and biofilms. In The Battle against Microbial Pathogens: Basic Science, Technological Advances and Educational Programs; Méndez-Vilas, A., Ed.; Formatex Research Center: Badajoz, Spain, 2015.

31. Muhammad, I.; Mossa, J.S.; El-Feraly, F.S. Antibacterial diterpenes from the leaves and seeds of Juniperus excelsa M. Bieb. Phyther. Res. 1992, 6, 261-264. [CrossRef]

32. Giweli, A.; Džamic, A.M.; Sokovic, M.; Ristic, M.S.; Marin, P.D. Antimicrobial and antioxidant activities of essential oils of satureja thymbra growing wild in libya. Molecules 2012, 17, 4836. [CrossRef]

33. Zhang, J.; Sun, H.; Chen, S.; Zeng, L.; Wang, T. Anti-fungal activity, mechanism studies on $\alpha$-Phellandrene and Nonanal against Penicillium cyclopium. Bot. Stud. 2017, 58. [CrossRef] [PubMed]

34. Li, L.; Shi, C.; Yin, Z.; Jia, R.; Peng, L.; Kang, S.; Li, Z. Antibacterial activity of $\alpha$-terpineol may induce morphostructural alterations in Escherichia coli. Braz. J. Microbiol. 2014, 45, 1409-1413. [CrossRef] [PubMed]

35. Han, Y.; Sun, Z.; Chen, W. Antimicrobial susceptibility and antibacterial mechanism of limonene against Listeria monocytogenes. Molecules 2020, 25, 33. [CrossRef] [PubMed]

36. Foerster, S.; Unemo, M.; Hathaway, L.J.; Low, N.; Althaus, C.L. Time-kill curve analysis and pharmacodynamic modelling for in vitro evaluation of antimicrobials against Neisseria gonorrhoeae. BMC Microbiol. 2016, 16, 216. [CrossRef] [PubMed] 
37. Adnan, M.; Patel, M.; Deshpande, S.; Alreshidi, M.; Siddiqui, A.J.; Reddy, M.N.; Emira, N.; De Feo, V. Effect of Adiantum philippense Extract on Biofilm Formation, Adhesion with Its Antibacterial Activities Against Foodborne Pathogens, and Characterization of Bioactive Metabolites: An In Vitro-In Silico Approach. Front. Microbiol. 2020, 11, 823. [CrossRef] [PubMed]

38. Brown, A.R.; Ettefagh, K.A.; Todd, D.A.; Cole, P.S.; Egan, J.M.; Foil, D.H.; Lacey, E.P.; Cech, N.B. Bacterial efflux inhibitors are widely distributed in land plants. J. Ethnopharmacol. 2021, 267, 113533. [CrossRef] [PubMed]

39. Costa, S.S.; Junqueira, E.; Palma, C.; Viveiros, M.; Melo-Cristino, J.; Amaral, L.; Couto, I. Resistance to antimicrobials mediated by efflux pumps in Staphylococcus aureus. Antibiotics 2013, 2, 83. [CrossRef]

40. Tariq, A.; Sana, M.; Shaheen, A.; Ismat, F.; Mahboob, S.; Rauf, W.; Mirza, O.; Iqbal, M.; Rahman, M. Restraining the multidrug efflux transporter STY4874 of Salmonella Typhi by reserpine and plant extracts. Lett. Appl. Microbiol. 2019, 69, 161-167. [CrossRef]

41. Hemaiswarya, S.; Kruthiventi, A.K.; Doble, M. Synergism between natural products and antibiotics against infectious diseases. Phytomedicine 2008, 15, 639-652. [CrossRef]

42. Simões, M.; Bennett, R.N.; Rosa, E.A.S. Understanding antimicrobial activities of phytochemicals against multidrug resistant bacteria and biofilms. Nat. Prod. Rep. 2009, 26, 746-757. [CrossRef]

43. Te Winkel, J.D.; Gray, D.A.; Seistrup, K.H.; Hamoen, L.W.; Strahl, H. Analysis of antimicrobial-triggered membrane depolarization using voltage sensitive dyes. Front. Cell Dev. Biol. 2016, 4, 29. [CrossRef]

44. Famuyide, I.M.; Fasina, F.O.; Eloff, J.N.; McGaw, L.J. The ultrastructural damage caused by Eugenia zeyheri and Syzygium legatii acetone leaf extracts on pathogenic Escherichia coli. BMC Vet. Res. 2020, 16, 1-9. [CrossRef]

45. Wang, C.C.; Yang, P.W.; Yang, S.F.; Hsieh, K.P.; Tseng, S.P.; Lin, Y.C. Topical simvastatin promotes healing of Staphylococcus aureuscontaminated cutaneous wounds. Int. Wound J. 2016, 13, 1150-1157. [CrossRef]

46. Amniattalab, A.; Mohammadi, R. Evaluation of antibiotic activity of methicillin in healing of fullthickness infected wounds with sensitized methicillin resistant Staphylococcus aureus in presence of HAMLET. Iran. J. Basic Med. Sci. 2018, 21, 1043-1049. [CrossRef]

47. Gupta, A.; Kumar, P. Assessment of the histological state of the healing wound. Plast. Aesthetic Res. 2015, 2, 239. [CrossRef]

48. Roy, S.; Santra, S.; Das, A.; Dixith, S.; Sinha, M.; Ghatak, S.; Ghosh, N.; Banerjee, P.; Khanna, S.; Mathew-Steiner, S.; et al. Staphylococcus aureus biofilm infection compromises wound healing by causing deficiencies in granulation tissue collagen. Ann. Surg. 2020, 271, 1174-1185. [CrossRef] [PubMed]

49. Tsugawa, H.; Cajka, T.; Kind, T.; Ma, Y.; Higgins, B.; Ikeda, K.; Kanazawa, M.; Vandergheynst, J.; Fiehn, O.; Arita, M. MS-DIAL: Data-independent MS/MS deconvolution for comprehensive metabolome analysis. Nat. Methods 2015, 12, 523-526. [CrossRef]

50. Weinstein, M.P.; Patel, J.B.; Bobenchik, A.M.; Campeau, S.; Cullen, S.K.; Galas, M.F.; Gold, H.; Humphries, R.M.; Kirn, T.J.; Lewis Ii, J.S.; et al. M100 Performance Standards for Antimicrobial Susceptibility Testing A CLSI Supplement for Global Application. Performance Standards for Antimicrobial Susceptibility Testing Performance Standards for Antimicrobial Susceptibility Testing; Clinical and Laboratory Standards Institute: Wayne, PA, USA, 2020; ISBN 9781684400324.

51. Abd El-Hamid, M.I.; El-Naenaeey, E.S.Y.; Kandeel, T.M.; Hegazy, W.A.H.; Mosbah, R.A.; Nassar, M.S.; Bakhrebah, M.A.; Abdulaal, W.H.; Alhakamy, N.A.; Bendary, M.M. Promising antibiofilm agents: Recent breakthrough against biofilm producing methicillin-resistant Staphylococcus aureus. Antibiotics 2020, 9, 667. [CrossRef]

52. Antibacterial Activity and Phytochemical Analysis of Cardanthera difformis Druce Leaf Extracts from West Bengal, India. Available online: https://www.researchgate.net/publication/287619737_Antibacterial_activity_and_phytochemical_analysis_of_ Cardanthera_difformis_druce_leaf_extracts_from_West_Bengal_India (accessed on 18 May 2021).

53. El-Banna, T.; El-Aziz, A.; Sonbol, F.; El-Ekhnawy, E. Adaptation of Pseudomonas aeruginosa clinical isolates to benzalkonium chloride retards its growth and enhances biofilm production. J. Agric. Food Chem. 2019, 46, 3437-3443. [CrossRef] [PubMed]

54. Sonbol, F.I.; El-Banna, T.E.; Abd El-Aziz, A.A.; El-Ekhnawy, E. Impact of triclosan adaptation on membrane properties, efflux and antimicrobial resistance of Escherichia coli clinical isolates. J. Appl. Microbiol. 2019, 126, 730-739. [CrossRef]

55. Kwak, Y.G.; Truong-Bolduc, Q.C.; Kim, H.B.; Song, K.H.; Kim, E.S.; Hooper, D.C. Association of norb overexpression and fluoroquinolone resistance in clinical isolates of Staphylococcus aureus from Korea. J. Antimicrob. Chemother. 2013, 68, 2766-2772. [CrossRef]

56. Livak, K.J.; Schmittgen, T.D. Analysis of relative gene expression data using real-time quantitative PCR and the $2^{-\Delta \Delta C T}$ method. Methods 2001, 25, 402-408. [CrossRef]

57. Zheng, J.; Tian, F.; Cui, S.; Song, J.; Zhao, S.; Brown, E.W.; Meng, J. Differential gene expression by ramA in ciprofloxacin-resistant Salmonella Typhimurium. PLoS ONE 2011, 6, 22161. [CrossRef]

58. Elekhnawy, E.; Sonbol, F.; Abdelaziz, A.; Elbanna, T. An investigation of the impact of triclosan adaptation on Proteus mirabilis/clinical isolates from an Egyptian university hospital. Braz. J. Microbiol. 2021, 52, 927-937. [CrossRef] [PubMed]

59. McDowell, E.M.; Trump, B.F. Histologic fixatives suitable for diagnostic light and electron microscopy-PubMed. Arch. Pathol. Lab. Med. 1976, 100, 405-414. [PubMed]

60. Suvarna, K.; Layton, C.; Bancroft, J. Bancroft's Theory and Practice of Histological Techniques-7th Edition, 7th ed.; Churchill Livingstone of Elsevier: Philadelphia, PA, USA, 2013.

61. Adibhesami, M.; Ahmadi, M.; Farshid, A.A.; Sarrafzadeh-Rezaei, F.; Dalir-Naghadeh, B. Effects of silver nanoparticles on Staphylococcus aureus contaminated open wounds healing in mice: An experimental study-PubMed. Vet Res Forum. 2017, 8, 23-28. [PubMed] 